\title{
Folkeafstemning og fødevareforsyning
}

\section{Ernærings- og forsyningsforhold i det slesvigske afstemningsområde 1918-20}

\author{
af MORTEN ANDERSEN
}

Opløsning af statslige tilhørsforhold og politiske styreformer skaber et politisk magttomrum, som kan blive kritisk, hvis autoriteternes fald får indflydelse på fødevareforsyningen. Det var tilfældet i det slesvigske afstemningsområde i perioden oktober 1918 til juni 1920, hvor en international kommission overtog den daglige administration, herunder fødevareforsyningen. Fødevaremangel, smughandel og valutaspekulation besværliggjorde opgaven, men fødevareforsyningen måtte på ingen måde få indflydelse på afholdelsen af frie og retfærdige afstemninger i Slesvig. Fødevareforsyningen fra Danmark gav anledning til det tyske skældsord "Speckdänen " om folk, der stemte dansk af materielle grunde. Men spørgsmålet er, om fødevareforsyningen fra Danmark eller den manglende ditto fra Tyskland vægtede mest, da det nationale tilhørsforhold kom til afstemning.

Den tyske krigsøkonomi havde i krigens fire år totalt omformet den daglige administration på alle områder. Det fik afgørende betydning for forsyningssituationen i Slesvigområdet efter oktober 1918. At fødevaremangel blev et problem i det krigsførende Tyskland, skyldtes manglende forberedelse på en langvarig krig. Da krigen brød ud i august 1914, taltes der i Tyskland om "sommerudflugten til Paris“. Den tyske generalstabskommando forventede, at krigen hejst ville vare ni måneder. Af den grund blev det ikke anset for nødvendigt at inddrage landbruget og fodevareindustrien i krigsforberedelserne. Marneslaget i september 1914 gjorde disse krigsplaner til skamme. Krigen var nu en stillingskrig, som man måtte forudse ville vare betydelig længere end forventet. De tyske myndigheder måtte derfor genoverveje forsyningssituationen. Efter at England i november 1914 indledte søblokaden, også kaldet "hungerblokaden", og afskar Tyskland fra livsvigtig import af kunstgødning og kraftfoder, blev det tyske samfund et mangelsamfund. Produktiviteten i landbruget faldt dra- 
stisk på grund af manglen på kraftfoder, kunstgødning og ikke mindst arbejdskraft efter indkaldelse af mange landmænd til militæret. Tysklands politiske og militære ledelse reagerede med at centralisere og udbygge krigsernæringsvæsenet. ${ }^{1}$

\section{Centralisering og totalmobilisering}

Allerede i august 1914 blev eksport af levnedsmidler og fodring med brødkorn forbudt. I efteråret 1914 blev der indført maksimalpriser og rationeringer på fødevarer som brødkorn og kød. Den 25. november 1914 oprettedes det almennyttige selskab, Kriegsgetreidegesellschaft, med det formål at sikre hæren og civilbefolkningens forsyning med brødkorn. Selskabet blev delt op i lokale afdelinger og fik den 17. december 1914 statslig koncession på indkøb af brødkorn ved landbruget. Fra januar 1915 skulle Kriegsgetreide-selskabet modtage $60 \%$ af brødkornshøsten i hver kreds. Kommunalforbundene skulle fordele og udligne afleveringsmængderne blandt større og mindre ejendomme. Disse kommunalforbund bestod af kredsen og dens kommuner og var en slags bedrift bestående af kommunale produktionsafdelinger. Kommuneforstanderne blev tildelt rollen som virksomhedsledere i det, der kunne minde om et kollektivbrug. Udover at sørge for inddrivelse og aflevering af brødkorn skulle kommuneforstanderne lede fordelingen af menneskelig og maskinel arbejdskraft mellem bedrifterne. De resterende $40 \%$ brødkorn til kredsens eget forbrug blev fordelt af enten Kriegsgetreide-selskabet eller Kommunalforbundet. Det sidste tilfælde krævede, at kredsen blev udnævnt til selvforsyningsøkonomi, "Selbstwirtschaft «. ${ }^{2}$

Hvad angik den lokale forsyning vedblev kredsene og kommunalforbundene at spille en væsentlig rolle under hele krigen. Men den statslige regulering af det tyske krigsernæringsvæsen blev stadig mere centraliseret. På samme måde som Kriegsgetreide-selskabet monopoliserede kornhandelen blev der dannet offentlige selskaber, der tog sig af kvæghandelen, smørhandelen og kulhandelen. I juni 1915 blev de lokale almennyttige Kriegsgetreide-selskaber afløst af et statsligt centralt Reichsgetreidestelle, og i maj 1916 samledes hele krigsernæringsvæsenet under Kriegsernährungsamt i Berlin. ${ }^{3}$ Med udnævnelsen af Hindenburg og Ludendorff til den øverste hærledelse i august 1916 og lanceringen af Hindenburgprogrammet med krav om totalmobilisering af det tyske samfund, kulminerede centraliseringen 
Tysk postkort med rationeringskort fra 1. verdenskrig. Med tiden blev alle fodevarer $i$ Tyskland rationeret under krigen. Som postkortet syrligt kommenterer var det ofte lettere at erhverve rationeringskortene end selve fødevarerationerne. Foto: Institut for Sønderjysk Lokalhistorie.

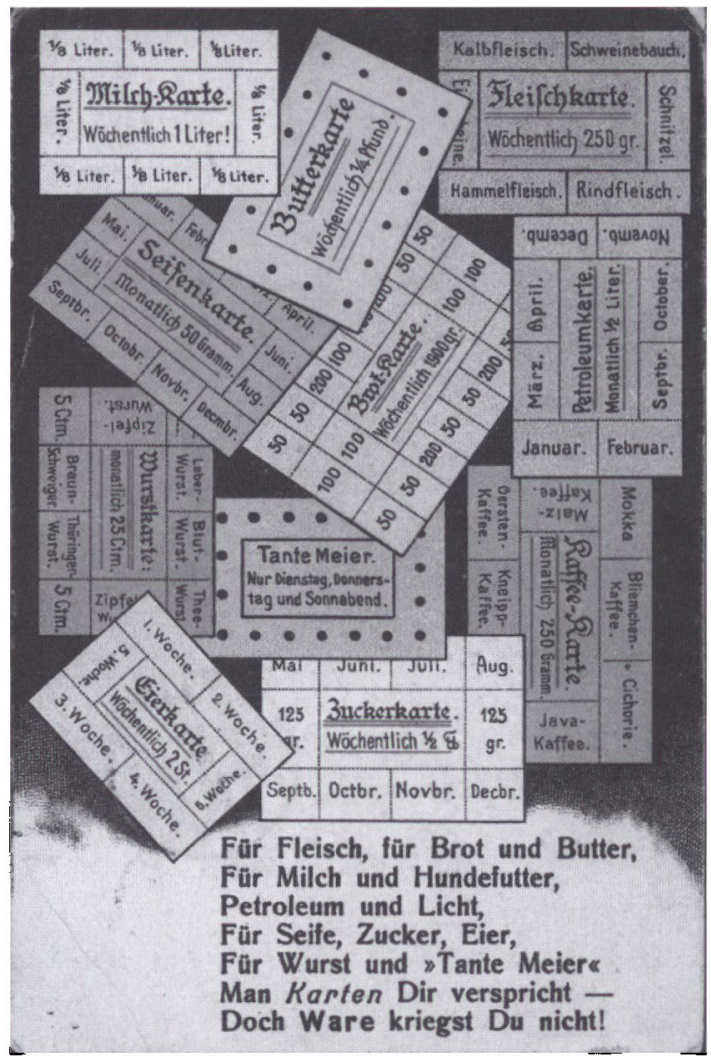

af den tyske krigsøkonomi. Et Kriegsamt med generalløjtnant Groener i spidsen blev nedsat med det formål at samle hele den tyske krigsøkonomi fra landbrug og ernæring til krigsindustri under ét tag. ${ }^{4}$

I 1916 slog høsten fejl. Vinteren 1916-17 blev siden betegnet som Kålrabivinteren, fordi roer var eneste tilgængelige fødevare. Reaktionen på den fejlslagne høst var øget kontrol af landbrugsproduktionen. I januar 1917 blev der på provinsniveau oprettet Kriegswirtschaftsämter og på kredsniveau Kriegswirtschaftsstellen. Begge institutioner stod direkte under Groeners Kriegsamt. Kriegswirtschaftsamt var øverste instans i alle krigsøkonomiske anliggender i provinsen og blev ledet af en militær embedsmand i samarbejde med overpræsidenten for provinsen. Kriegswirtschaftsamts opgave var at sørge for tilvejebringelse og fordeling af bedriftsledere, arbejdere, arbejdsheste, maskiner, og brændstof samt forvaltningen af jernbanenettet og trans- 
portspørgsmål. ${ }^{5}$ Kriegswirtschaftstelles opgaver var de samme som Kriegswirtschaftamts blot på kredsniveau. Først og fremmest skulle Kriegswirtschaftstelle sørge for indbringelse af høsten i 1917. Kriegswirtschaftstelle bestod af den lokale landråd samt 4-8 lokalt landbrugssagkyndige. Kommunalforbundene bibeholdt deres opgaver lokalt, men stod under Kriegswirtschaftstelles myndighed.

\section{Tysklands sammenbrud}

I 1917 tog de sociale og politiske uroligheder i krigens Tyskland til. ${ }^{6}$ Urolighederne hang sammen med de stærkt stigende priser. Hindenburgprogrammet havde forøget den statslige efterspørgsel på industriproduktionen betragteligt og tillod samtidig arbejdslønningerne at stige på grund af manglen på arbejdskraft og frygten for social uro. Det skabte en løn- og prisspiral, der sammen med den tyske rigsbanks dækningsløse krigsfinansieringspolitik førte til en stadig stigende inflation. De fastsatte maksimalpriser på fødevarer tog ikke del i prisstigningerne. Det betød, at landmændenes udgifter snart oversteg indtjeningen. Det sorte marked, hvor indtjeningen var betydelig bedre, blev derfor mere og mere attraktivt. Sidst i 1917 blev sortbørshandelen så omfattende, at det officielle distributionssystem kom på sammenbruddets rand. Tilliden til det statslige distributionssystem undermineredes totalt. Det tyske samfund splittedes og demoraliseredes, og en følelse af at være uretfærdigt ramt af krigsøkonomien bredte sig $i$ alle samfundslag. ${ }^{7}$

I september 1918 var grænserne for Tysklands ydeevne nået. Den nye tyske regering under Max von Baden bad 4. oktober 1918 præsident Wilson om våbenstilstand med udgangspunkt i præsidentens 14 punkter for en europæisk fredsløsning. Wilson accepterede dog kun en betingelsesløs kapitulation, hvilket fik den tyske hærledelse til at overveje genoptagelse af krigshandlingerne. Løbet var imidlertid kørt for Tysklands militære ledelse. Ludendorff tog sin afsked, og kejseren abdicerede. En politisk revolution tog nu sin start, men blev snart kontrolleret af det tyske socialdemokrati SPD. Den 9. november 1918 udråbte Philip Scheidemann republikken Tyskland i Berlin, og den 11. november 1918 underskrev finansminister Mathias Erzberger våbenstilstandsaftalen med ententemagterne. ${ }^{8}$

Det var med en våbenstilstand på præsident Wilsons præmisser i udsigt, at de dansksindede nordslesvigeres leder H.P. Hanssen den 23. ok- 
også i Slesvigområdet, hvor det nationale spørgsmål virkede i samme retning. De dansksindede nordslesvigere, der havde været under fremmedherredømme siden 1864, kunne endelig løsne deres frygt for de preussiske myndigheder.

Fødevareforsyningen var stadig i de tyske myndigheders hænder. Under revolutionen i november 1918 blev der dannet soldater-og arbejderråd, som blandt andet havde fødevareforsyningen som arbejdsområde. Rådene havde dog haft så relativ kort en levetid, at de aldrig fik afgørende indflydelse på fødevaresituationens karakter. Revolutionens hurtige uddøen og SPD's overtagelse af magten betød, at det tyske krigsernæringsvæsen foreløbig blev opretholdt. Reguleringerne, rationeringerne og maksimalpriserne kunne ikke ophæves uden videre. Således skrev lederen af Kriegswirtschaftsamt Slesvig-Holsten til samtlige Kriegswirtschafstellen i provinsen den 11. november 1918: »Krigsamt-staben meddeler hermed, at af hensyn til levnedsmiddel- og kulforsyningen samt demobiliseringen skal tjenesten opretholdes i fuld omfang, herunder også de enkelte Kriegwirtschafstellen. " $^{10}$

Mens ententens statsledere forhandlede om fredstraktaten i Paris i foråret 1919, koncentrerede Tyskland sig om demobiliseringen af sine soldater. Det gik ikke stille af, og perioden januar til april 1919 var præget af voldsomme uroligheder og mange strejker i de tyske storbyer og kulminedistrikter, hvor hjemvendte soldater krævede deres gamle arbejde tilbage. Det lykkedes i nogen grad den tyske regering at genindsætte mange af de hjemvendte soldater i deres gamle arbejde, men prisen var stigende lønninger. ${ }^{11}$ Det betød, at inflationen fortsatte med uformindsket styrke, og at sortbørshandelens priser fulgte trop i samme eller stærkere styrke.

I Slesvigområdet forstærkedes denne udvikling af forventningen om overgangen til dansk styre og økonomi. Den mere værdifulde danske kronemønt blev i løbet af foråret 1919 indført som måleenhed for handel med ejendomme og spredte sig efterhånden til enhver form for handel. Det trak både priser og lønninger op. Landmændene fik det problem, at mens de måtte sælge deres afgrøder til de fastsatte maksimalpriser i tyske reichsmark, krævede landarbejderne deres lønninger udbetalt $\mathrm{i}$ danske kroner. Smughandelen, som allerede var kraftigt udviklet under krigen, tog nu voldsomt til, da landmændene her kunne få langt højere priser for deres produkter. Myndighederne havde derfor store vanskeligheder ved at indhente det afleveringspligtige korn og kvæg. 


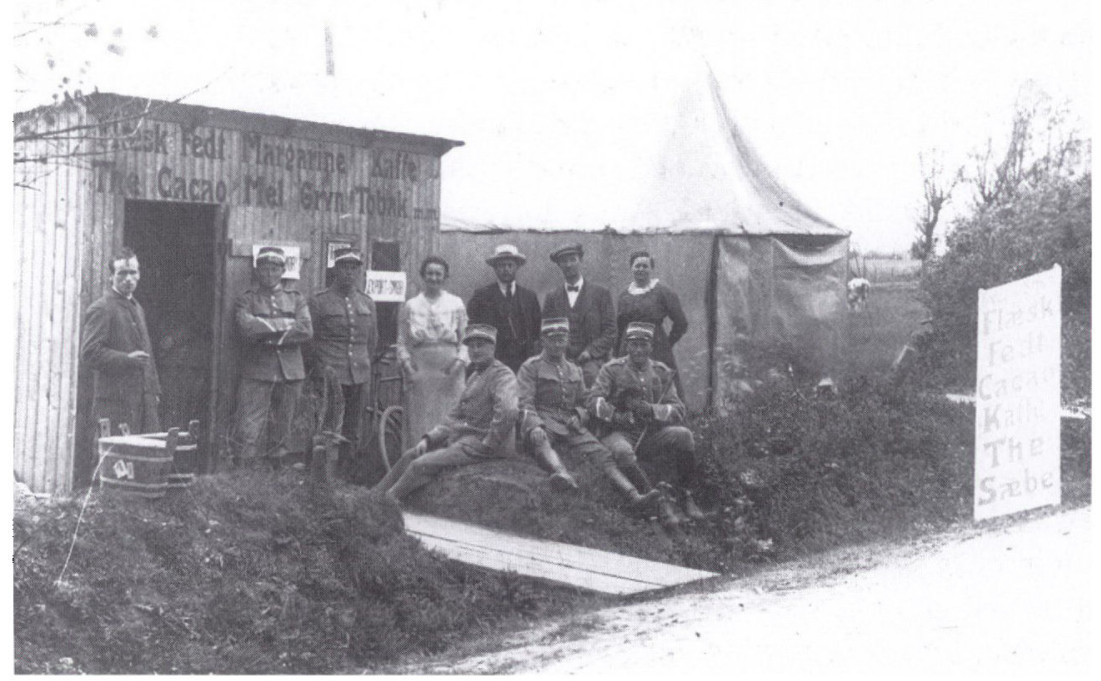

"Grænsekiosk" ved Bajstrup, Kongeågrænsen 1919. Nord for Kongeågrænsen fandt sønderjyderne alle de varer, der var utilgængelige $i$ Tyskland. I 1918-19 tog grænsetrafikken til, og egentlige grænsekiosker blev etableret som her $i$ Bajstrup. Foto: Institut for Sonderjysk Lokalhistorie.

Samtidig gav Nordslesvigs forventede overgang til dansk styre anledning til betydelig økonomisk spekulation. I foråret 1919 oplevede Nordslesvig en invasion af tyskere og tyske firmaer. Fra 1. januar til 1. oktober 1919 etablerede 65 firmaer sig i Haderslev by, heraf kun 5 danske. Omkring 4.000 nye tilflyttere pressede ejendomspriser i vejret. I Aabenraa var 40 nye firmaer tilmeldt handelsregistret i perioden fra 1. oktober 1918 til 1. juli 1919, i Sønderborg 32. Indlån i de Nordslesvigske banker steg fra 132 millioner mark i december 1918 til 287 millioner mark i december 1919. ${ }^{12}$ Det var tysk kapitalflugt fra finansminister Erzbergers skatteprogram og spekulation i den kommende valutaregulering, der her sås udfoldet. Samtidig tog trafikken over den nordlige grænse til Danmark til. For 10 pfenning kunne personer, der boede nær grænsen, købe endagspas til Danmark. Det blev udnyttet til at gøre store indkøb af ellers utilgængelige varer, som efterfølgende kunne sælges med god fortjeneste i Nordslesvig. Dertil kom, at mange nordslesvigere optog kronelån i Danmark, for med den værdifulde kronemønt at afløse deres gæld i tyske mark. Der blev optaget lån på den konto for omtrent 60 millioner kroner i 1919. ${ }^{13}$ 
Kronelånene og den organiserede smughandel var stærkt medvirkende til at forvride forholdet mellem det officielle og det reelle prisniveau. 14. juli 1919 var der arrangeret storstrejke og fællesmøde på torvet $i$ Haderslev af de samvirkende fagforeninger, som protesterede mod de høje fødevarepriser og smughandelen. Samme dag blev et tolvmandsråd nedsat i Haderslev af de to socialdemokratiske partier, kommunisterne og Sønderjysk Arbejderforening med henblik på at skride til handling mod den stadig forværrede ernæringssituation. Arbejderen Peter J. Møller skriver om dette udvalg og tilstandene i Haderslev i foråret 1919 i sine erindringer om tiden 1914-40: "Levnedsmiddelkrisen var akut, og det hjalp kun lidt, at et nedsat tolvmandsråd, der havde noget $i$ retning af politimyndighed, drog rundt til egnens bønder og beslaglagde svin og andre næringsmidler. [...] I Haderslev prægedes tilværelsen af strejker og uro, og så selvfølgelig forventningerne om den folkeafstemning, der skulle bestemme landsdelens fremtid. [...] Respekten for autoriteterne var rejst samme vej som kejseren. Sortbørshandel og smugleri hørte til dagens orden. Vareknapheden ramte hårdt og allermest dem, der havde mistet alt, hvad de ejede, og hvor manden var gået til i krigen. $O g$ mens nogle fejrede store orgier, fandtes den mest udprægede fattigdom i mange små hjem. « ${ }^{14}$

\section{H.P. Hanssen og ernæringsforholdene i afstemningsområdet}

Landråd von Löw i Haderslev modtog den 26. juli 1919 meddelelse om, at Kriegswirtschaftstelle Haderslev skulle nedlægges og kredsudvalget overtage dets opgaver. Meddelelsen kom fra den preussiske indenrigsminister via overpræsidenten i Kiel. ${ }^{15}$ Dermed blev landråderne og kredsudvalgene igen øverstansvarlige for kredsens forsyningssituation. Det må også noteres, at reguleringssystemet fortsat blev opretholdt. Rationeringer, maksimalpriser og tvangsafleveringer udgjorde stadig kernen i det officielle ernæringsvæsen. Reichsgetriedestelle, Viehhandelsverein og kommunalforbundene eksisterede fortsat, selvom handelen udenom institutionerne var omfattende.

I maj 1919 indtrådte H.P. Hanssen som minister i det midlertidige ministerium for sønderjyske anliggender på opfordring af statsminister Zahle. Formålet var både praktisk og politisk. H. P. Hanssen skulle med sit store kendskab til sønderjyske forhold hjælpe regeringen med at forberede Nordslesvigs genforening med Danmark, men også 
Minister for sonderjyske anliggender H.P. Hanssen. (1862-1935). Som minister juni 1919 til marts 1920 udrettede H.P. Hanssen et stort arbejde for genforeningens praktiske udforelse. Også forsyningssituationen $i$ afstemningsområdet fik H.P. Hanssens opmærksomhed. Foto: Institut for Sønderjysk Lokalhistorie.

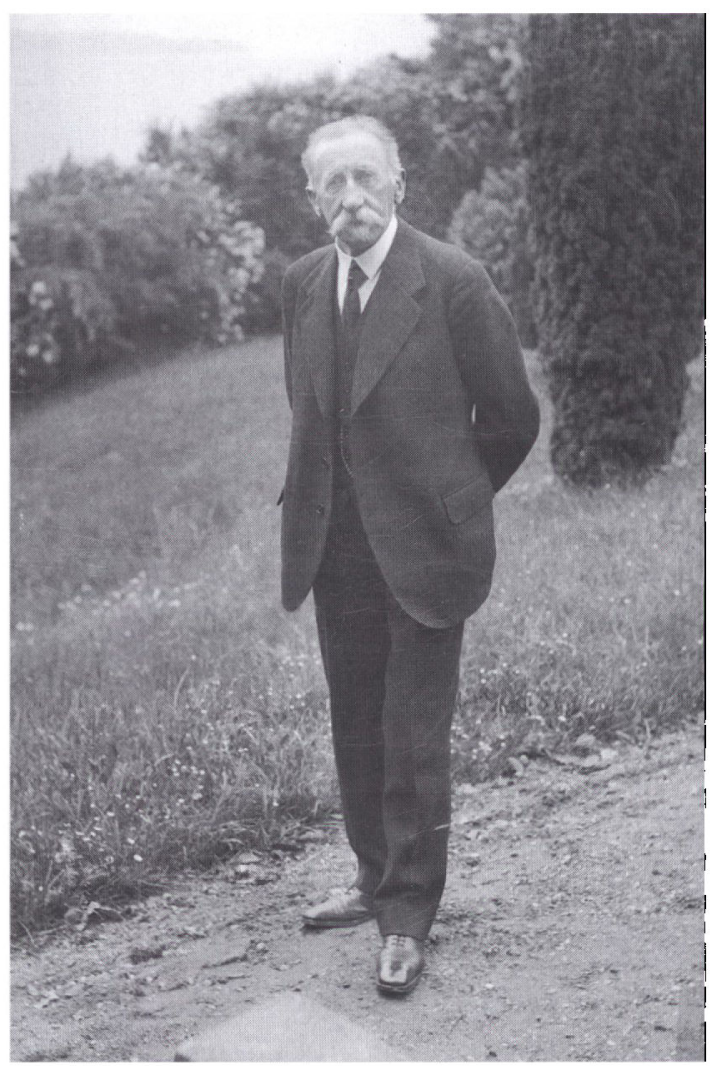

sikre den radikale regering rygdækning for sin grænsepolitik. Polemikken om den nye grænses beliggenhed blev med H.P. Hanssens indtræden i den radikale regering kraftig skærpet, og H.P. Hanssen måtte tage mod mange øretæver fra Flensborg-fløjen i den nordslesvigske vælgerforening. ${ }^{16}$ Ikke desto mindre fik det midlertidige ministerium for sønderjyske anliggender udrettet et stort arbejde omkring de praktiske forhold ved genforeningen. Intet emne undgik ministeriet og dets to medarbejderes opmærksomhed, heller ikke ernærings- og forsyningssituationen i afstemningsområdet. ${ }^{17}$

Afstemningsområdets ernærings- og forsyningssituation lå H.P. Hanssen meget på sinde $\mathrm{i}$ hans tid som minister, hvilket ses af hans store engagement $i$ sagen. H.P. Hanssen har formentlig betragtet fodevaremangel og sult som problemer, der kunne medføre sociale uroligheder i afstemningsområdet og i værste fald forhindre afstemnin- 
gernes afholdelse. Det var derfor vigtigt, at afstemningsområdet blev tilstrækkelig forsynet med fødevarer i afstemningstiden. Men der var også en anden problemstilling i afstemningsområdets fødevareforsyning, der kunne få uheldige følger for det nationale spørgsmåls afgørelse. Hvor skulle forsyningerne komme fra, og hvem skulle betale? Afstemningsområdets forsyning kunne blive udnyttet i den nationale valgkamp, og det ville svække afstemningernes legitimitet alvorligt. Her lå måske den største fare. Tyskland var i forvejen særdeles kritisk indstillet til afstemningerne og ville benytte enhver lejlighed til at rejse spørgsmålstegn ved afstemningernes legitimitet. Det har formentlig også været en del af H.P. Hanssens overvejelser. Slesvigspørgsmålet skulle nu, én gang for alle, afgøres, og det måtte ernærings- og forsyningsforhold ikke forpurre.

Det skulle imidlertid vise sige sig ganske vanskeligt at holde ernærings- og forsyningsforholdene $i$ afstemningsområdet skarpt adskilt fra både danske og tyske nationale interesser. Således kunne minister H.P. Hanssen den 10. juli 1919 overfor Rigsdagspartiernes sønderjyske Udvalg, der var nedsat som rådgivende organ omkring lovgivningen ved Nordslesvigs indlemmelse i Danmark, berette, at både Haderslev og Sønderborg kredse ville løbe tør for brødkorn, før den nye høst $i$ august kunne fylde lagrene op. Ministeren havde derfor via det danske ernæringsråd sørget for, at der ville blive sendt brødkorn til Haderslev fra Danmark på kredit til efteråret. Den tyske regering havde på grund af den tiltagende inflation forbudt udførsel af reichsmark, hvilket nødvendiggjorde kreditten til Haderslev. Lignende arrangementer måtte gennemføres i de andre kredse. Desuden var der opstået problemer med kultilførslen fra Tyskland. Gasværker, elektricitetsværker og mejerier stod uden kul og måtte indstille driften. Ministeren havde her arrangeret, at kultilførsler fra Tyskland beregnet for Danmark i stedet blev bragt til Nordslesvig. ${ }^{18}$ Afstemningsområdets forsyninger kunne på den måde sikres ved tilførsler fra Danmark. Men lå der ikke netop en konflikt med princippet om adskillelse af forsyning og national politik her?

\section{Den internationale kommission CIS}

Fredstraktaten fra Paris var blevet offentliggiort den 7. maj og underskrevet af Tyskland - om end i protest - den 28. juni 1919. Resultatet af traktaten blev for Slesvigs vedkommende to folkeafstemninger. Én 
en-bloc-afstemning $i$ området ned til en linie syd om Tønder og nord om Flensborg, og én distriktsvis afstemning i Mellemslesvig. Til at gennemføre afstemningerne blev Commission internationale de Surveillance du plebicite au Schleswig (CIS) nedsat. ${ }^{19}$ Kommissionen skulle udover at gennemføre afstemningerne også stå for den daglige administration af området. Dertil kunne kommissionen om fornødent erstatte tyske myndigheder og lade sig bistå af tyske og danske rådgivere, valgt blandt den stedlige befolkning. Afgørende var det, at kommissionen kun havde almindelig forvaltningsmyndighed. Tyskland beholdt sin suverænitet over afstemningsområdet, indtil en ny grænse var fastlagt. Det skulle blive årsag til en del tekniske vanskeligheder $i$ forbindelse med Nordslesvigs overgang til dansk styre. ${ }^{20}$ Formand for kommissionen blev den britiske gesandt i København Sir Charles Marling. Frankrig valgte også sin gesandt i København Paul Claudel til medlem, mens Norge valgte telegrafdirektør Thomas Heftye og Sverige landshøvding i Gøteborg Oscar von Sydow. Sekretær for kommissionen, vel at betragte som femte medlem, blev englænderen Charles Brudenell-Bruce.

I august 1919 samledes medlemmerne af den internationale kommission i Kobenhavn for at forberede sig på afstemningen og administrationen. Der blev udarbejdet et reglement for afstemningerne, og embedsmænd og rådgivere blev udpeget. H.P. Hanssen og det midlertidige ministerium lå fra start i tæe dialog og samarbejde med CIS. Ernæringsforholdene var en af de første berøringsflader mellem CIS og det midlertidige ministerium, og $i$ august 1919 forsøgte de to parter at udarbejde en model for forsyningsforholdene $i$ afstemningstiden.

\section{Selvforsyning og kompensation}

H.P. Hanssen kunne den 20. august 1919 overfor Rigsdagspartiernes sønderjyske Udvalg berette, at en deputation fra Flensborg havde været hos ham for at tale om ernæringsforholdene. Deputationen havde udtalt frygt for, at når CIS overtog styret, ville fødevarepriserne stige til kroneniveau. Det ville betyde priser 2-3 gange så høje som de nuværende. Deputationen havde derfor foreslået, at de tyske rationeringer og maksimalpriser blev opretholdt til fordel for forbrugerne under CIS' styre. Dette synspunkt kunne H.P. Hanssen tilslutte sig. Men han mente også, at basale livsfornødenheder som kød, brød, smør, 
margarine og gryn skulle tilføres fra Danmark. I så fald ville der opstå et tab i forhold til indkøbet af danske varer til kronepriser. I Versaillestraktaten var det blevet fastlagt, at omkostningerne ved CIS' administration af afstemningsområdet skulle deles ligeligt af Danmark og Tyskland. Det måtte også gælde for forsyningerne til afstemningsområdet og udligningen af det omtalte tab skulle således deles af Danmark og Tyskland. H.P. Hanssen havde talt med flere medlemmer af CIS, der også kunne tilslutte sig opretholdelsen af de tyske rationeringer og maksimalpriser. I praksis skulle kommunalforbundene købe fødevarer i Danmark og sælge disse videre til de nordslesvigske forbrugere til tyske maksimalpriser. Kommunerne skulle så efterfølgende have erstatning for det opståede tab. H.P. Hanssen bad udvalget om mandat til at forhandle med CIS og de tyske myndigheder om en sådan løsning, hvilket blev ham givet. ${ }^{21}$

Landråd Böhme fra Tønder kreds blev i august 1919 udpeget til den tyske regerings repræsentant overfor den internationale kommission. Böhme var dermed også repræsentant i spørgsmålet om ernæringsforhold sammen med den af Tyskland i april 1919 udnævnte statskommissær for Slesvig, Adolf Köster. Den 29. august berettede H.P. Hanssen overfor Rigsdagspartiernes sønderjyske Udvalg, at han med landråd Böhme havde opnået en foreløbig aftale om gensidige leveringsforpligtelser, som skulle godkendes af det preussiske indenrigsministerium og det stående udvalg for kredsudvalgene i Sønderjylland. Aftalen indebar, at afstemningsområdet blev selvforsynende med brødkorn og samtidig fritaget for at aflevere brødkorn til Reichgetreidestelle. Derimod skulle afstemningsområdet aflevere kvæg til Viehhandelsverein efter det gennemsnit, der leveredes over hele Tyskland med fradrag af kvæg til afstemningsområdets eget forbrug. Til gengæld ville Tyskland forsyne afstemningsområdet med sukker og kul i hele afstemningsperioden. Det ville, sagde H.P. Hanssen, være en særdeles fordelagtig ordning, da man for et forholdsvist lille antal kvæg ville få sikkerhed for kul- og sukkerforsyning. ${ }^{22}$

Med forslaget blev selvforsyning med brødkorn og kvæg som kompensation for kul for første gang præsenteret som hovedprincipper $i$ afstemningsområdets forsyning. Ideen om selvforsyning og kompensation som grundlag for en ordning kan meget vel være udviklet gennem det midlertidige ministeriums samarbejde med CIS. Ministeriet og CIS havde en fælles interesse i at holde ernærings- og forsyningsspørgsmålet adskilt fra nationale interesser i afstemningsområdet, 
hvilket netop var formålet med selvforsyning og kompensation. Men det var langt fra uden problemer at nå til en gensidig anerkendelse af dette princip og senere også at få ordningen til at fungere efter hensigten. H.P. Hanssens forslag om tilførsel af fødevarer fra Danmark til afstemningsområdet skulle i praksis vise sig bedre egnet til at opfylde afstemningsområdets forsyningsbehov. Til gengæld havde denne løsning problemer med den nationale neutralitet.

\section{Varebeslaglæggelser}

Den internationale kommission skulle, som i alle andre forhold, finde en neutral position mellem de danske og tyske synspunkter omkring forsyningssituationen. Det skulle blive en svær balanceakt. Toldgrænsen blev et ømtåleligt problem for CIS, fordi toldgrænseforholdene hang nært sammen med suverænitetsforholdene i afstemningsområdet. Som omtalt beholdt Tyskland den egentlige suverænitet over afstemningsområdet indtil den formelle grænsenotifikation den 15. juni 1920, mens CIS havde almindelig forvaltningsmyndighed. På forespørgsel af H.P. Hanssen havde CIS tidligt afvist, at der kunne indføres toldfrie varer fra Danmark $i$ afstemningstiden. Toldgrænsen ville forblive ved Kongeåen, indtil Danmarks overtagelse af administrationen af hensyn til den fortsatte tyske suverænitet og Tysklands anerkendelse af CIS. Det betød også, at fødevarer fra Danmark ikke uden videre kunne tilføres afstemningsområdet. Der lå ellers, ifølge H.P. Hanssen, varelagre ophobet i Kolding med henblik på indførsel til Nordslesvig, hvor de fleste varelagre var tomme. De tyske myndigheder var af en anden opfattelse.

I slutningen af august 1919 beslaglagde tyske myndigheder flere varelagre i Nordslesvig med den begrundelse, at de var samlet med henblik på senere fordelagtige danske salgspriser. H. P. Hanssen skrev den 30. august 1919 til formanden for CIS, Charles Marling, om sagen. Der kunne være tale om spekulationsophobning i de tilfælde, hvor varelagrene tilhørte tyske firmaer, der var tilflyttet Nordslesvig. Men også hos den hjemmehørende handelsstand havde beslaglæggelserne fundet sted. Det var ifølge H.P. Hanssen ikke rimeligt, da handelsstanden nu engang havde behov for fyldte varelagre. Han bad derfor CIS om at reagere og hindre beslaglæggelserne. Marling svarede samme dag. Den tyske gesandt i København, von Neurath, havde i en skrivelse til den danske udenrigsminister Scavenius anført, at beslag- 
læggelserne var rettet mod "hamstrere« og ikke mod den normale hjemmehørende handel. Charles Marling havde tillid til den tyske regerings hensigt, men mente, at de embedsmænd, der udførte beslutningen, beslaglagde mere end tilsigtet. ${ }^{23}$

Charles Marling har givetvis henvendt sig til den tyske statskommissær Köster, da denne ifølge Aabenraa-avisen Hejmdal henvendte sig til H.P. Hanssen mandag den 1. september 1919 for at drøfte beslaglæggelserne. H.P. Hanssen var denne dag til møde på Folkehjem i Aabenraa med fællesrepræsentationen for Handelsforeningen i Nordslesvig. Et udvalg fra fællesrepræsentationen og H.P. Hanssen blev enige med statskommissær Köster om, at beslaglæggelserne af varelagre hos den i Nordslesvig hjemmehørende handelsstand skulle ophøre, og at de allerede beslaglagte varer skulle frigives. Derimod skulle beslaglæggelser fra firmaer, der havde bosat sig i Nordslesvig siden 1. oktober 1918 ikke frigives. ${ }^{24}$ Påstanden om vareophobning var bestemt ikke uden realitet, men var et reelt problem i de områder af Tyskland, der enten var besat eller stod overfor en ændring af statstilhørsforhold. ${ }^{25}$ Adolf Köster havde med rette sat ind overfor dette fænomen for at forhindre spekulative gevinster ved overgangen til Danmark. Men hvornår var der tale om hamstring med henblik på økonomisk gevinst ved overgangen, og hvornår var der tale om at handelstanden blot holdt sine varelagre tilstrækkeligt fyldte med henblik på regulær salg til befolkningen? Beslaglæggelserne var på den måde et eksempel på, at forsyning og nationale interesser var svære at holde adskilt $i$ den statsretslige overgangsperiode.

\section{Mødet i Flensborg 4. oktober 1919}

Som omtalt var H.P. Hanssen den 1. september 1919 til møde på Folkehjem i Aabenraa med fællesrepræsentationen for handelsforeningen. Her deltog også Fælleslandboforeningens bestyrelse, kredsudvalgene for de nordslesvigske kredse og hovedbestyrelsen for Sønderjysk Arbejderforening. Formålet var en drøftelse af Nordslesvigs forsyning med fødevarer og livsfornødenheder samt toldspørgsmålet og indførselsreglerne i den tid, CIS skulle administrere området. På mødet blev man enige om at rette en henvendelse til CIS med anbefalinger til forsyningsordningen. For det første blev det anbefalet, at landbruget fortrinsvis leverede produkter til afstemningsområdet, og kun sydpå i mængder svarende til leveringen af kul, sukker og 
byggematerialer fra Tyskland. For det andet blev det anbefalet, at levnedsmidler skulle leveres fra Danmark til nordslesvigske forretninger til danske rationeringspriser. Varetilførslen fra Danmark skulle fortoldes efter normale satser og ikke med krav om betaling i guld, som Tyskland krævede. Vigtigst var det, at indforsler til afstemningsområdet ikke blev gjort afhængig af de tyske myndigheder. ${ }^{26} \varnothing$ nskerne blev fremlagt for CIS i en henvendelse fra det midlertidige ministerium den 6. september 1919. Ministeriet anbefalede samtidig, at der blev optaget forhandlinger med de lokale tyske myndigheder om forsyningssituationen. Senere i september foranledigede det midlertidige ministerium nedsættelsen af en 5-mandskommission med ernæringssituationen $\mathrm{i}$ afstemningsområdet som arbejdsfelt. Kommissionen bestod af de af CIS designerede amtmænd A. Karberg, Sønderborg, redaktør Kresten Refslund-Thomsen, Aabenraa og grev O.D. Schack, Tønder, samt tandlæge J. Schmidt fra Haderslev og professor i fysiologi ved Landbohøjskolen og medlem af det danske ernæringsråd og statens brødkornsadministration Holger Møllgaard.

Den 4. oktober 1919 blev et møde mellem 5-mandskommissionen, det midlertidige ministerium og lokale tyske myndigheder arrangeret af CIS. Mødet fandt sted i Flensborg og fra tysk side deltog statskommissær Köster, flensborgske senatorer, de fem nordslesvigske landråder og repræsentanter fra Provinsial Fettstelle i Kiel. Sidstnævnte institution havde ansvar for distributionen af fedtstof i provinsen. Som repræsentant for CIS deltog det svenske medlem Oscar von Sydows sekretær konsul Lundgreen.

Det viste sig, at kredsene Haderslev, Sønderborg, Aabenraa og Tønder på hver deres måde kompenserede landmændene økonomisk for forskellen mellem tyske og danske maksimalpriser for at tilskynde afleveringerne til kredsene. De kielske ernæringsmyndigheder kritiserede disse ordninger skarpt, men 5-mandskommissionen fastholdt, at hvis ikke landmændene blev økonomisk kompenseret, ville afleveringspligten aldrig blive opfyldt. Aftalen blev derfor at lade de enkelte kredse administrere afleveringer til kredsenes eget forbrug på den mest hensigtsmæssige måde.

Landråderne havde til mødet medbragt talmateriale fra de enkelte kredses ernæringsadministrationer. Ved en sammenholdning af dette talmateriale blev deltagerne enige om, at afstemningsområdet producerede tilstrækkeligt med fødevarer til både at forsyne sig selv og til at sende sydpå som kompensation for kul, sukker og bygningsmateri- 


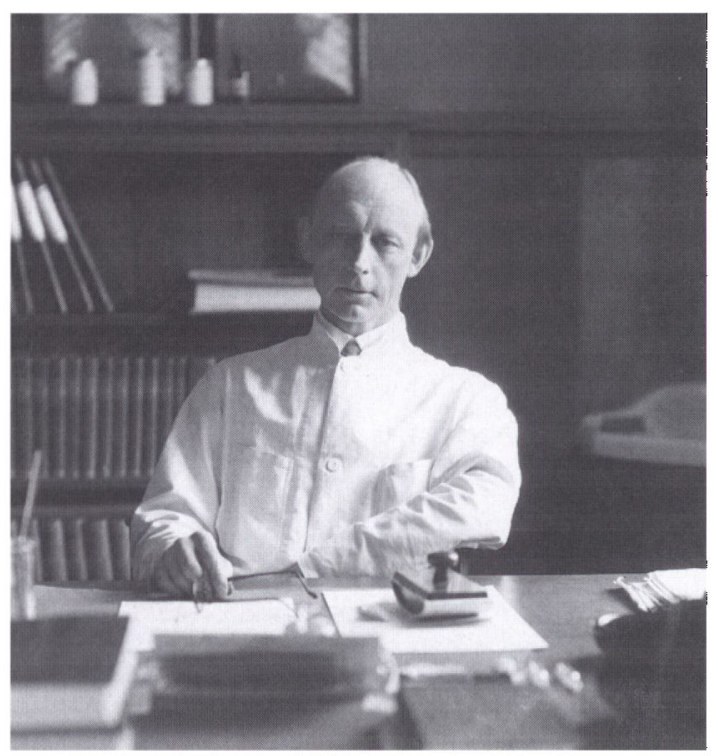

Professor i fysiologi ved Landbohøjskolen og ernxringsrådgiver for CIS Holger Mollgaard (18851973). Marten Refslund Poulsen, Bovlund, skrev $i$ sine erindringer om professoren: "Mollgaard var en elegant og beslutsom herre, der vel hørte pã vore meninger, men så sagde han, hvorledes det skulle være. Og han havde evne og magt«. Portræt fra 1936. Foto: Det Kongelige Bibliotek.

aler. Der fandtes et ugentligt overskud på 390 stykker kvæg af 600 pund, som kunne udføres til Tyskland. Ligeledes kunne der udføres 36.000 pund smør ugentligt fra afstemningsområdet. Denne udførsel ville i tyske maksimalpriser svare til to millioner mark om måneden. Problemet var, at alene afstemningsområdets månedlige kulforbrug udgjorde en værdi af tre millioner mark, hvortil kom forbrug af sukker og byggematerialer. Det var således ikke muligt at udføre så mange varer fra afstemningsområdet, som der var behov for varer fra Tyskland. Alligevel enedes deltagerne om, at kompensationsmetoden kvæg og smør for kul og sukker var en ønskelig ordning. De ovennævnte udførselsmængder, 390 stykker kvæg og 36.000 pund smør om ugen, blev derfor fastholdt. Som kontrolinstans for denne kompensationsordning skulle der oprettes et fælles Ernæringsråd under CIS' myndighed. Rådet skulle have en rådgivende funktion i ernæringsspørgsmål overfor CIS og landbrugstekniske rådgivere tilknyttes rådet i hver kreds. Rådet skulle desuden bestå af lige mange danskere og tyskere. ${ }^{27}$ Når deltagerne kunne enes om denne ordning, var det fordi princippet om selvforsyning og kompensation var en national neutral løsning. Ingen befolkningsgrupper blev særligt begunstiget ved ordningen, og samtidig kunne ordningen ikke udnyttes i den nationale propaganda. Derfor kunne også CIS stå inde for ordningen. 
Der var imidlertid for mange løse ender $\mathrm{i}$ aftalen, ikke mindst det ulige kompensationsforhold. Alle leveringer blev modsat hensigten stort set indstillet efter den 4 . oktober.

\section{Professor Holger Møllgaard og 5-mandskommissionen}

Årsagen til at kvægafleveringerne fra afstemningsområdet til de tyske myndigheder blev indstillet, var blandt andet markkursens meget voldsomme fald i efteråret 1919. Forholdet mellem de tyske maksimalpriser og den kronepris, landmændene kunne få på det sorte marked, blev dermed endnu større. Incitamentet til at beholde kvæg og brødkorn, indtil Nordslesvig var blevet dansk, var derfor stort, særligt da overgangen forventedes at blive gennemført umiddelbart efter afstemningerne først i 1920. Af samme årsag blev der også bragt kvæg fra Sydslesvig til Nordslesvig. Først og fremmest skyldtes indstillingen af kvægafleveringerne, at Viehhandelsverein af ukendte årsager ikke inddrev kvæget. Tyskland holdt til gengæld også kulleverancerne tilbage. Haderslev, Aabenraa og Sønderborg kredse havde siden foråret 1919 ikke fået tilført tilstrækkeligt med kul. Det gav problemer for elektricitetsværker, mejerier og produktionen i det hele taget. På den baggrund tog det midlertidige ministerium og H.P. Hanssen initiativ til en konference om levnedsmiddelspørgsmålet i København den 5.-6. november 1919 med deltagelse af repræsentanter for den danske regering og 5-mandskommissionen. Sidstnævnte påtog sig i den anledning at udarbejde et nyt forslag til en ordning af levnedsmiddel- og forsyningsadministrationen $i$ afstemningsområdet under CIS. ${ }^{28}$

Professor i fysiologi Holger Møllgaard blev med sin ekspertise hovedkraften i 5-mands-kommissionens arbejde og siden i afstemningsområdets forsyningsadministration som sådan.

Det midlertidige ministerium havde udpeget professor Møllgaard til 5-mandskommissionen og så ham også gerne i det ernæringsråd, man havde ønsket oprettet på mødet den 4. oktober. Problemet med professor Møllgaard var, at CIS' rådgivere skulle findes i den hjemmehørende slesvigske befolkning. Det gav de tyske myndigheder anledning til at modsætte sig professor Møllgaards udnævnelse til rådet. Sidst i november 1919 anerkendte de tyske myndigheder dog Møllgaard som dansk repræsentant $i$ afstemningsområdets ernærings- og 
forsyningsadministration. Professor Møllgaards rapporter og indberetninger til CIS og de danske myndigheder er et centralt kildemateriale til denne bihistorie om folkeafstemningen i Slesvig 1920.

\section{Levnedsmiddelkonferencen 5.-6. november 1919}

Professor Møllgaard var bagmand til forslaget om ordning af levnedsmiddeladministrationen, som 5-mandskommissionen fremlagde på levnedsmiddelkonferencen den 6. november 1919. I forslaget blev kerneproblemet $\mathrm{i}$ afstemningsområdets forsyningssituation beskrevet i klare ord: Problemet var de uforenelige interesser hos henholdsvis forbrugere og producenter. De tyske maksimalpriser måtte opretholdes af hensyn til forbrugerne. Men de tyske maksimalpriser betød også, at landmændenes incitament til at sælge deres produkter på det sorte marked til langt højere priser var meget stort. 5-mandskommissionen foreslog derfor, at den danske stat efterbetalte landmændene differencen mellem tyske og danske priser på brødkorn, når Danmark overtog administrationen. Dog kun for det korn, der var afleveret før administrationsovertagelsen og endnu ikke var brugt. Desuden måtte kredsenes lokale levnedsmiddelordninger bestå indtil den danske overtagelse af administrationen. På den måde kunne der tages hensyn til både forbrugere og producenter.

Med hensyn til kvæg-for-kul-ordningen var det, som omtalt på mødet den 4 . oktober, ikke muligt at udføre tilstrækkeligt med fødevarer fra afstemningsområdet til Tyskland til at udligne værdien af kul- og sukkertilførsler fra Tyskland. Her pegede 5-mandskommissionen på den mulighed, at Danmark trådte hjælpende til og kompenserede Tyskland for kulleverancerne med korn eller margarine. Afstemningsområdet måtte så vidt muligt opretholde sin selvforsyning med fødevarer og altså ikke sende større mængder fødevarer sydpå. Indtil videre måtte den gældende kompensationsordning mellem Tyskland og afstemningsområdet opretholdes, men forhandlinger mellem den danske og tyske regering om kompensationer her i mellem måtte snarest optages. Forslaget krævede en bevilling fra den danske stat til at efterbetale de nordslesvigske landmænd for deres afleverede brødkorn. Bevillingen lød på 1,5 millioner kroner, hvis der regnedes med en periode på tre måneder til dansk overtagelse af administrationen. Grundlæggende kunne bevillingen og tilførslerne fra Danmark løse de største forsyningsproblemer, mente 5-mandskommissionen. 
Et vigtigt punkt i forslaget var også, at der skulle sættes ind overfor smughandelen over Kongeåen og Lillebælt ved øget grænsepatruljering. ${ }^{29}$ Udvalget knyttede nogle bemærkninger til forslaget, hvori det blev påpeget at: "under hensyn til, at samtlige repræsentanter stærkt fremhævede, at der herskede den største lovløshed i afstemningsområdet, specielt med hensyn til forordningen vedrørende levnedsmidler, er man enedes om nødvendigheden af, at de tyske former saa snart som gørligt afløses af danske, der menes at ville kunne vente større lydighed hos befolkningen og tillige vil frembyde større muligheder for områdets levnedsmiddelforsyning, fordi der derved opnås intimere tilknytning til den kongerigske administration. ${ }^{30}$ Møllgaard pegede her på mistilliden til de tyske statsreguleringer og det magtpolitiske tomrum, der prægede afstemningsområdet. Dette tomrum skulle snarest udfyldes af danske regler og administration. Problemet var imidlertid, at hvis folkeafstemningerne skulle tages alvorligt, kunne der ikke indføres danske regler og administration, før afstemningerne var afholdt. Der var til gengæld heller ingen tvivl om, at zone 1 ville have dansk flertal. Derfor var befolkningen også begyndt at indrette sig på indlemmelse i Danmark. Princippet om national neutralitet $\mathbf{i}$ den daglige administration af afstemningsområdet var på mange måder uforenelig med de faktiske tilstande.

\section{Mandatet af 26. november 1919}

Der skulle gå yderligere tre uger, før de tyske ernæringsmyndigheder godkendte Mølgaard som dansk repræsentant i ernæringsadministrationen, og derfor blev forhandlinger med Tyskland om forsyningsforholdene ikke optaget. Da Møllgaard endelig blev anerkendt den 24. november, var forsyningssituationen $\mathrm{i}$ afstemningsområdet yderligere forværret, hvilket også var årsag til de tyske myndigheders accept af Møllgaard. Nu skulle forhandlingerne i gang, men den forværrede situation nødvendiggjorde endnu en revidering af det danske forhandlingsoplæg. 26. november 1919 redegjorde H. P. Hanssen og Holger Møllgaard i fællesskab for et revideret udkast til en levnedsmiddelordning i Rigsdagspartiernes sønderjyske Udvalg. Forslaget krævede nu en bevilling på 4.020 .000 kroner fra den danske stat.

Professor Møllgaard ridsede endnu en gang problemerne i afstemningsområdets ernærings- og forsyningsforhold op. På grund af mangel på kraftfoder var smørproduktionen stærkt faldende, og selv om- 
rådets eget forbrug kunne vanskeligt opfyldes. Kul- og sukkerleverancer fra Tyskland var, med undtagelse af leverancer til Flensborg, minimale. De gældende maksimalpriser blev omgået på alle mulige måder. Smør blev solgt til 25-50 mark pr. pund, mens den officielle maksimalpris var 11,20 mark pr. pund. Priserne på alle varer i handelen steg voldsomt. Arbejdere forlangte stadig højere lønninger, som regel i danske kroner. Forskellen mellem de priser, landmændene kunne få for deres varer, og den pris, de måtte betale for gødningsstoffer og lønninger, var efterhånden så stor, at de måtte nægte at aflevere til tyske maksimalpriser. Kerneproblemet var at: "Fristelsen til at tilbageholde varerne eller sælge dem i smughandel er så uhyre stor, at det ikke er underligt, at begge dele sker i stor udstrækning. Der menes, at der er dels opfodret og dels solgt i smughandel så meget brødkorn, at afstemningsområdet ikke længere vil kunne forsyne sig selv høståret ud. « ${ }^{31}$

Løsningen på disse problemer havde fem hovedprincipper, der i store træk svarede til 5-mandskommissionens oplæg af 6 . november i udvidet form. Smughandelen måtte frem for alt standses. Det krævede en fuldstændig afspærring af hele afstemningsområdet ved forøget grænsepatruljering. Med hensyn til landmændenes afleveringsincitament var det nødvendigt, at de sønderjyske landmænd fik det brødkorn, de afleverede efter den 1. december 1919 til afstemningsområdets eget forbrug, betalt i kroneværdi 25 kroner pr. 100 kilo korn. Det ville i alt koste 500.000 kroner i måneden, og hvis der blev regnet med en overgang til dansk styre den 1. april $1920 \mathrm{i}$ alt to millioner kroner. Kvæget måtte landmændene til gengæld aflevere til tysk maksimalpris med en mindre kompensation fra kredsen. Kulleverancerne fra Tyskland måtte løses fra kompensationsprincippet, da afstemningsområdet ikke kunne levere tilstrækkeligt til gengæld for kullet. Her måtte den danske stat træde til og kompensere Tyskland ved at levere korn hertil. Det ville koste staten 700.000 kroner. Fødevarer måtte tilføres afstemningsområdet fra Danmark, men uden at forhøje priserne yderligere, blandt andet margarine til en værdi af 1.320 .000 kroner over de fire måneder. Sammenlagt en udgift på 4.020 .000 kroner for den danske stat.

Med denne bevilling mente Møllgaard, at tålelige forhold kunne etableres $\mathbf{i}$ afstemningsområdet og roen så nogenlunde sikres. Af stor betydning var ifølge Møllgaard også kronemøntens indførelse i Nordslesvig. Valutaspørgsmålet lå på dette tidspunkt til forhandling i et af 
Det sønderjyske Udvalg nedsat undervalg. Om dette spørgsmål sagde Møllgaard: "Spørgsmålet er, som sagt, ikke gennemdebatteret endnu, men jeg har villet omtale det her for at henlede opmærksomheden på, at økonomiske spørgsmål i Slesvig, netop fordi forsyningsvanskelighederne er så store, ikke kan løses alene ved en valutaordning, som den, der hidtil har været omdisputeret, men kræver, at der snarest muligt efter dansk besættelse må skaffes kronemønt ned i landet. ${ }^{32}$ Møllgaard henviste her til finansminister Brandes' foreslag af 30 . juli 1919 om en afregningskasse, der skulle etableres i Nordslesvig og yde kronelån mod deponering af kontante markbeløb eller tilgodehavender i banker og sparekasser. ${ }^{33}$ Afregningskassen og kronemøntens indførelse kunne imidlertid først iværksættes, når Danmark havde overtaget administrationen af området. Møllgaard lod forstå, at kronemønten måtte indføres snarest muligt af hensyn til de prisforskelle, der herskede i området og den nødtilstand, der var opstået heraf. Møllgaard havde her en væsentlig pointe. De usikre valutaforhold var $i$ høj grad et problem i ernærings- og forsyningsforholdene i overgangstiden mellem dansk og tysk administration. Og det skulle ikke blive bedre.

Flere af det sønderjyske udvalgs medlemmer fandt Møllgaards forslag temmelig kompliceret, men valgte alligevel at stemme for bevillingen, da de uholdbare forhold i afstemningsområdet talte for det. Møllgaard kunne således tage mere end 4 millioner kroner med til forhandlingerne med de tyske myndigheder. At bevillingen i sig selv kunne skabe vanskeligheder, var Møllgaard klar over. Som han skrev i sin beretning til Rigsdagspartiernes sønderjyske Udvalg i april 1920 om forhandlingerne med de tyske repræsentanter: "Hvis dette forslag kunde gennemføres, måtte det ventes at hidføre en væsentlig forbedring i hele forsyningssituationen for den nordslesvigske befolkning. Man var imidlertid ikke blind for, at forslaget i virkeligheden krævede en overenskomst imellem den danske og tyske regering med den internationale kommissions tilslutning, ligesom man heller ikke manglede blik for, at forslaget indeholdt sådanne bestemmelser, som muligvis kunne møde ret stærk modstand fra tysk side, idet de kunne opfattes som forsøg på at påvirke afstemningen til gunst for Danmark. « ${ }^{34}$ Der var en fare for, at den danske bevilling kunne opfattes som et led i den nationale propaganda, hvilket kunne betyde tysk modstand og værre endnu true Tysklands anerkendelse af den endelige afstemning. Møllgaard forsvarede bevillingen med de akutte krise- 
forhold, og det er vanskeligt at forestille sig, at det sønderjyske udvalg og den danske stat skulle sidde Møllgaards advarsler overhørig. H.P. Hanssen talte i samme anledning sågar om borgerkrigslignende tilstande. Hensynet til opretholdelsen af den sociale og politiske ro vejede tungere end hensynet til national neutralitet. Men de tyske myndigheder skulle stadig overbevises om, at dette forslags gennemførelse var tvingende nødvendigt.

\section{Ernæringsrådgivernes fælles forslag}

I perioden fra den 14. til den 23. december 1919 førte professor Møllgaard forhandlinger med den af Tyskland udnævnte ernæringsrådgiver Willy Iversen, Munkbrarup, samt repræsentanter fra henholdsvis nordslesvigske landboforeninger og kredse samt regionale tyske ernæringsmyndigheder. Professor Møllgaard blev på grund af sit velforberedte forslag den ledende skikkelse $\mathrm{i}$ forhandlingerne. Både de nordslesvigske og tyske forhandlingspartnere kunne kun bidrage med marginale ændringsforslag. Vigtigt var det, at Møllgaards forslag blev støttet af den tyske ernæringsrådgiver Iversen, og at Møllgaard og Iversen tidligt udøvede et pragmatisk samarbejde.

Den 22. december 1919 lå et fælles forslag til en levnedsmiddelordning klar til CIS, underskrevet af ernæringsrådgiverne Møllgaard og Iversen, statskommissær Köster, landråd Siemon, Aabenraa, formand for Schleswig-Holsteinischer Viehhandelsverein samt M. C. Bartels fra Provenzial Fettstelle i Kiel. Forslaget indeholdt de fem punkter, der svarede til Møllgaards udkast fra den 26 . november. Som tillæg til udkastet udarbejdede Møllgaard en rapport til CIS, hvori udkastet blev nærmere forklaret. Her skrev Møllgaard blandt andet, at den tyske ernæringsadministrations opretholdelse af tvangsforholdsregler, der var fuldstændig uholdbare som følge af udviklingen, var hovedårsag til lovlesheden på forsyningsområdet. ${ }^{35}$ Efter en gennemgang af de enkelte forsyningsområder sluttede Møllgaard med ordene: "Der kan næppe herske nogen tvivl om, at væsentlige ændringer snarest må ske, hvis det skal lykkes at opretholde en blot nogenlunde rimelig forsyning af afstemningsområdet ved hjælp af dets egne produkter, hvilket må siges at være meget ønskeligt, hvis man vil undgå, at der blandes nationalpolitik ind i forsyningsvæsenet. «" Møllgaard hævdede hermed, at en nationalpolitisk udnyttelse af ernæringssituationen kunne afværges med det fælles forslag til er- 
næringsordningen. Men spørgsmålet var, om det fælles forslag i sig selv var nationalpolitisk værdifrit?

Det fælles løsningsforslag på de omfattende forsyningsproblemer var som omtalt et fempunktsprogram. Punkt ét handlede om en fuldstændig afspærring af afstemningsområdet til lands og til vands, så udførsel af fødevarer blev standset. Punkt to omhandlede misforholdet mellem de gældende tyske maksimalpriser på korn og det øvrige prisniveau. Dette misforhold skulle udlignes ved, at landmændene fik erstatning i kronemønt for det korn, de havde leveret til Reichgetreidestelle inden 15. februar 1920, og som endnu ikke var blevet brugt, når dansk administration blev indført. Stod landmanden derimod i restance med kornafleveringen, når dansk administration blev indført, ville de resterende mængder leveringspligtig korn kun skulle betales med tyske maksimalpriser. Punkt tre sagde, at de tyske maksimalpriser på brødkorn måtte bestå på forbrugssiden. Punkt fire, at det til Viehhandelsverein afleverede kvæg blev betalt i tyske maksimalpriser med tillæg for huden. Punkt fem, at indtil dansk suverænitet var indtrådt, bestod Tysklands leveringsforpligtelser med hensyn til kul, sukker og byggematerialer. Til gengæld ville afstemningsområdet være selvforsynende med de resterende fødevarer samt forpligte sig til at levere det kvæg, der ikke var blevet afleveret i tiden fra 1. august 1919 til 31. januar 1920. Det skulle indhentes ved levering af cirka 1.900 stykker kvæg om ugen fra den 1. januar 1920 og syv uger frem. Dertil kom de 390 stykker kvæg ugentligt indtil dansk administrationsovertagelse, samt levering af 36.000 pund smør ugentligt. Var der leveringsrestancer ved indførelsen af dansk administration, ville henholdsvis den tyske og danske regering være ansvarlig for efterbetaling. ${ }^{37}$ Det skulle vise sig, at flere involverede parter $i$ forsyningsproblematikken ikke fandt forslaget helt nationalpolitisk retfærdigt.

\section{Kvægafleveringerne}

Det mest omstridte punkt i udkastet var det ikke afleverede kvæg. Kvægtællingen af 1. december 1919 havde vist, at der befandt sig 264.148 stykker kvæg i hele afstemningsområdet. Det var 20.235 flere, end der havde været den 1 . september samme år. Denne forøgelse kunne ikke skyldes naturlig vækst alene, men beroede på, at betydelige mængder kvæg var drevet op sydfra for at blive solgt til kronepriser. Den mængde kvæg, der ikke var blevet afleveret, udgjorde kun 


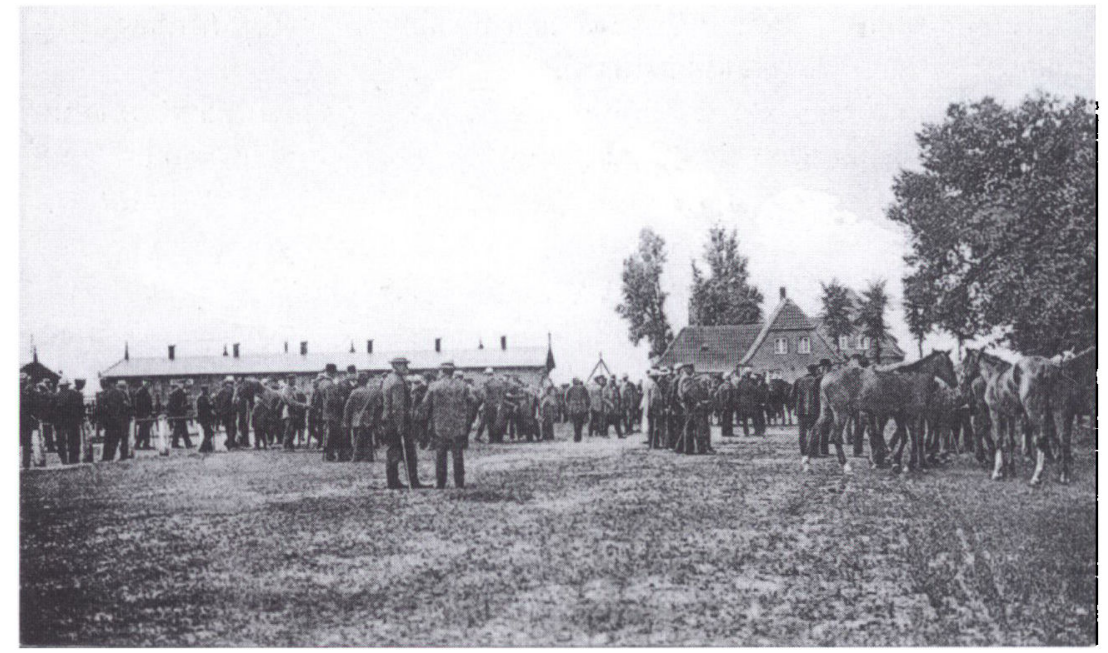

Kvægmarkedsplads $i$ Tonder fra tysk tid. Modstanden mod tvangsafleveringerne af kvæg til Viehhandelsverein var stærk $i$ Tonder kreds under krigen, udtrykt ved oprettelsen af protestbevægelsen Schleswig-Holsteinischer Bauernverein. Kvægafleveringerne til Folkeforsyningsrådet under CIS blev heller ikke uden videre accepteret p̊̊ Tønderegnen. Foto: Institut for Sønderjysk Lokalhistorie.

11.737 stykker. Den samlede levering frem til den 1 . juni 1920 til kredsenes egen forsyning til Flensborg og til kompensation for kul fra Tyskland ville kun udgøre omtrent 7-8\% af den samlede kvægmængde $i$ afstemningsområdet. Af den grund mente professor Møllgaard ikke at kunne afvise det tyske krav på kvægrestancerne. ${ }^{38}$

Udkastet blev ikke modtaget venligt af den sønderjyske presse. At der skulle afleveres i alt 11.737 stykker kvæg, fordi Nordslesvig stod i restance, forekom aldeles urimeligt, da Tyskland ikke havde leveret kul siden oktober 1919. Man var forundret over, at CIS skulle arbejde i Tysklands sag og inddrive kvæg til Viehhandelsverein. ${ }^{39}$ På grund af denne uro indkaldte CIS de designerede landråder og repræsentanter for landboforeningerne til møde med kommissionen og ernæringsrådgiverne den 6. januar 1920. Generalsekretær Brudenell-Bruce indledte mødet med at oplæse en erklæring af CIS. Kommissionen havde stor tillid til de to ernæringsrådgiveres ekspertise og anså det fremlagte forslag til forsyningsordningen for det bedst egnede $i$ de nuværende omstændigheder. Forslaget opfyldte det overordnede princip bag CIS' fødevarepolitik, om hvilket Brudenell-Bruce udtalte: »Det er den internationale kommissions bestemte intention ikke at 
tillade spørgsmål om fødevareforsyning eller rent kommercielle emner at hindre udførelsen af en fri og retfærdig afstemning. ${ }^{40}$ Den foreslåede erstatning for det afleverede brødkorn i kronemønt var altså ifølge CIS ikke i strid med princippet om adskillelse af fødevareforsyning og nationalpolitik. Det skulle vise sig, at de tyske myndigheder var uenige på det punkt.

Under forhandlingerne med Viehhandelsverein og de tyske myndigheder havde professor Møllgaard let forundret spurgt, hvorfor Viehhandelsverein ikke havde inddrevet det afleveringspligtige kvæg i afstemningsområdet siden august 1919. Hertil svarede man, at der fra fredskonferencen i Paris var sendt en note til den tyske regering, som forbød Tyskland at rekvirere kvæg i afstemningsområderne. Møllgaard bad CIS om at fremskaffe denne note fra fredskonferencen til opklaring af ordlyden. Den 7. januar kom der telegram fra Paris med svar. Det var ganske rigtigt bestemt, at de tyske militære og civile myndigheder skulle afholde sig fra ethvert indgreb i afstemningsområdernes økonomiske liv, herunder også rekvisioner af fødevarer, indtil besættelsen med allierede tropper fandt sted. Det betød, at der med ét kunne slås en streg over de 11.737 stykker kvæg, afstemningsområdet skyldte Tyskland. Dermed var en stor knast $i$ overenskomstforhandlingerne fjernet. Kvægafleveringsaftalen skulle kun dreje sig om den tid, hvor CIS administrerede afstemningsområdet. Efterhånden syntes en overenskomst mulig.

\section{Den internationale kommission træder til}

Den 10. januar 1920 blev ratifikationerne af Versaillestraktaten endelig udvekslet i Paris, og samme dag bestemte CIS, at afstemningerne i Slesvig skulle afholdes 10. februar og 14. marts. En række anordninger angående praktiske forhold i CIS’ regeringstid blev også udstedt den 10. januar. Her i blandt anordning $\mathrm{nr}$. $19 \mathrm{om}$ oprettelsen af et tilsynsråd for befolkningens forsyning med levnedsmidler. Rådet skulle beskæftige sig med "spørgsmål vedrørende afstemningsområdets forsyning med levnedsmidler, kul og byggematerialer samt leveringen fra afstemningsområdet til Tyskland af kvæg og smør i henhold til vedføjede overenskomst«. Tilsynsrådet fik »besluttende myndighed i ethvert spørgsmål, som ligger indenfor dets kompetence. Dog skal de for rådets virksomhed nødvendige pengemidler anvises af den internationale kommission «. I alle principielle spørgsmål skul- 
le tilsynsrådet indhente udtalelse ved ernæringsrådet i Flensborg. ${ }^{41}$ Der var således tale om et overordnet tilsynsråd og et rådgivende ernæringsråd. Ernæringsrådet var identisk det råd, man den 4. oktober 1919 havde besluttet at oprette, men som endnu ikke var trådt $i$ officiel funktion. Tilsynsrådets to medlemmer var professor Holger Møllgaard og gårdmand Willy Iversen. Ernæringsrådets medlemmer var endnu ikke udnævnt.

To dage senere, den 12. januar 1920, fulgte $i$ anordning nr. 20, en overenskomst mellem den internationale kommission og den tyske regering om afstemningsområdets forsyning med forskellige varer fra Tyskland. Overenskomsten, der var udarbejdet af ovennævnte tilsynsråd og godkendt af landråd Böhme, indeholdt de kompensationsbestemmelser, der længe havde været til forhandling. Den tyske regering skulle levere kul, sukker, cement og andre byggematerialer til afstemningsområdet. Til gengæld ville CIS pålægge de enkelte kredse at aflevere så meget kvæg, at der samlet ville være 390 stykker kvæg om ugen fra afstemningsområdet rede til udførsel til Tyskland. Værdien af kvæget skulle svare til værdien af det indførte kul. Men, som det hed, "skulle værdien af det fra Tyskland indførte kvæg overstige værdien af de 390 stykker kvæg, skal kommissionen dække værdidifferencen ved udførsel af andre landbrugsprodukter ${ }^{42}{ }^{42}$ Forslaget om, at afstemningsområdet skulle eksportere 36.000 pund smør ugentlig, var gledet ud af overenskomsten. I stedet skulle CIS dække værdidifferencen mellem kvæget og kullet. Her var et smuthul, som skulle blive det i praksis fungerende princip. CIS dækkede gennem hele sin regeringstid værdidifferencen mellem kulleverancer fra Tyskland og kvægleverancer fra afstemningsområdet med margarine fra Danmark.

Overenskomsten omhandlede kun kompensationsordningen kvægfor-kul. Derimod var kornordningen og selvforsyningsprincippet ikke nævnt. Det skyldtes, at den tyske regerings repræsentant, Böhme, og statskommissær Köster havde afvist professor Møllgaards forslag om efterbetaling i kronepriser til de nordslesvigske bønder. Forslaget var blevet sendt til regeringen i Berlin, og her blev kornordningen afvist, fordi regeringen anså ordningen for at have væsentlig indflydelse på afstemningsresultatet. Den lovede erstatning til de slesvigske landmænd fra dansk side kunne den tyske regering ikke betale, hvorfor de slesvigske landmænd her fik en materiel grund til at stemme for Danmark. Endnu en gang skulle der forhandles om et kompromis.

På et ekstraordinært møde i København den 24. januar 1920 mellem 


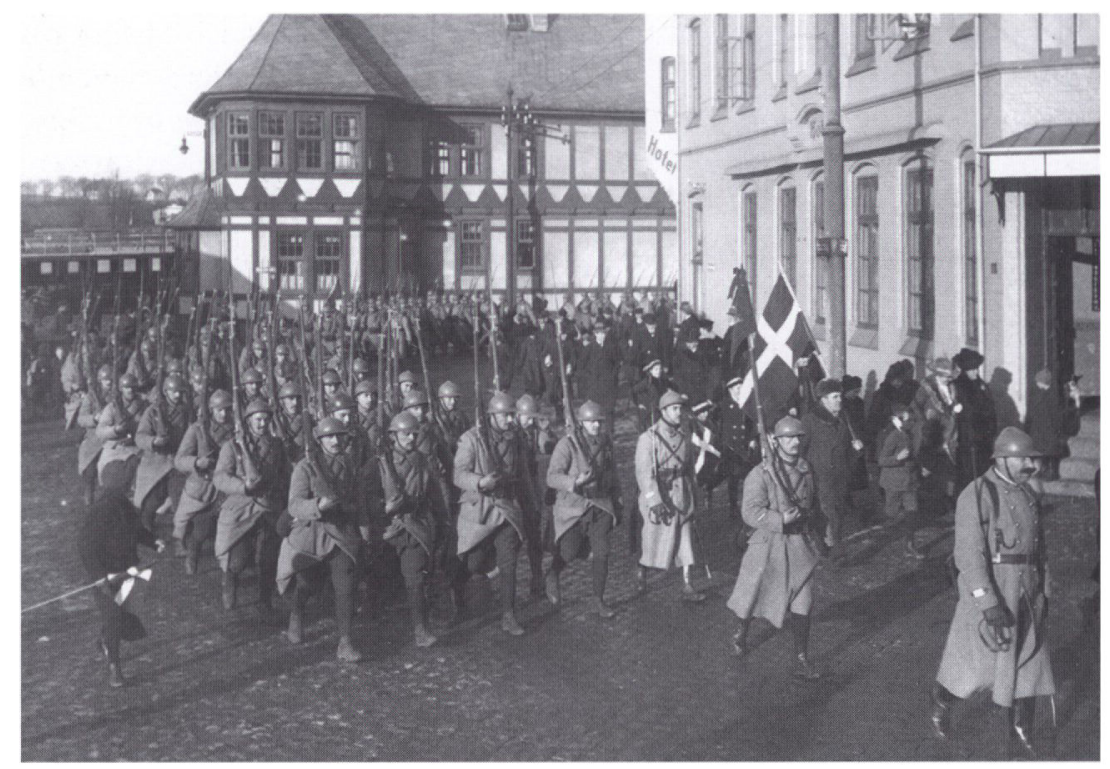

Franske alpejægere på march $i$ Sønderborg. En international besættelsesstyrke bestående af 3000 soldater fra Frankrig og England skulle give synligt bevis for afstemningsomrddets internationale status og var mest af symbolsk verdi. Politiopgaver og paskontrollen ved afstemningsområdets grænser blev derimod varetaget af et hjælpepolitikorps bestående af tidligere tyske soldater med dansk sindelag. Foto: Institut for Sønderjysk Lokalhistorie.

CIS, tilsynsrådet og den danske regering blev tre modeller diskuteret. CIS kunne rekvirere kornet hos de slesvigske landmænd uden at love efterbetaling, hvilket var den tyske regerings onske. CIS kunne også aftale efterbetalingsordningen med den danske regering alene og siden kræve den tyske regering til regnskab for halvdelen af omkostningerne. En tredje mulighed var, at CIS købte korn ved den danske regering til forsyning af de forsørgelsesberettigede i afstemningsområdet. Prisen skulle være $\mathrm{i}$ overensstemmelse med de eksisterende maksimalpriser og det tab, den danske regering herved fik, senere deles ligeligt mellem Danmark og Tyskland. CIS valgte den sidste løsning, og straks derefter blev der sendt $6.380 \mathrm{hkg}$. rugmel og 3.170 hkg. hvedemel fra danske kornlagre til afstemningsområdet svarende til 14 dages forbrug. ${ }^{43}$ Beslutningen blev truffet udenom den tyske regerings repræsentant og statskommissær Köster.

Det blev den gældende ordning for kornleveringen gennem hele afstemningstiden. De nordslesvigske landmænd beholdt deres korn, 
og i stedet blev området forsynet med korn fra Danmark. I februar tilførtes $12.459 \mathrm{hkg}$. rug og $10.030 \mathrm{hkg}$. hvede, som blev malet på nordslesvigske møller. I løbet af februar og marts 1920 forhandlede CIS med de tyske myndigheder om Tysklands indtræden i ordningen. Aftalen blev, at Tyskland leverede cirka $10.000 \mathrm{hkg}$ korn månedlig, hvilket svarede til omtrent $1 / 3$ af afstemningsområdets forbrug. ${ }^{44}$ Når Danmark fra begyndelsen kunne levere korn til afstemningsområdet, var det fordi professor Møllgaard med bevillingen på 4 mio. kr. i november 1919 havde sikret sig en finansiel aftale med den danske stat. Nu kom denne bevilling til at dække tilførsler til afstemningsområdet og Tyskland og ikke efterbetaling for brødkorn til nordslesvigske landmænd. Indtil videre kunne landmændene beholde deres brødkorn.

\section{Anordning af 26. januar 1920 om Folkeforsyningsrådets myndighed}

Den 26. januar 1920 udstedte CIS anordning nr. 22 omhandlende Folkeforsyningsrådets myndighed. Tilsynsrådet fik titlen Folkeforsyningsrådet og dets myndighed blev udstrakt til alle dele af forsyningssituationen, herunder forsyning med fødevarer, kvæg og foderstoffer, fordeling og rationering, fastsættelse af maksimalpriser og udveksling med varer fra Tyskland. Dernæst hed det at, "samtlige kredses ernæringsadministrationer og enhver institution, forretning og person, der er knyttet til disse, er underordnet Folkeforsyningsraadet $0 g$ vil have at adlyde dets ordrer og anvisninger «. ${ }^{45}$ Det var uindskrænket magt på forsyningsområdet, der blev Folkeforsyningsrådet til del. Rådets beføjelser var at sammenligne med det tyske Kriegswirtschaftsamts beføjelser, og kommunalforbundene blev underlagt Folkeforsyningsrådets myndighed på samme måde. Det blev i samme anordning meddelt, at kredsudvalgene hver især skulle vælge medlemmer til det rådgivende ernæringsråd. Ernæringsrådet måtte have 18 medlemmer, hvoraf de 6 skulle repræsentere forbrugerne. Haderslev, Aabenraa og Sønderborg kredse skulle hver vælge én dansk forbrugerrepræsentant, mens Flensborg, Flensborg landkreds og Tønder hver skulle vælge én tysk forbrugerrepræsentant. Men ernæringsrådet var alene rådgivende.

Efter anordningen fulgte en bekendtgørelse fra Folkeforsyningsrådet angåede kvægafleveringerne. Her blev det fastslået, at afstem- 
ningsområdet skulle aflevere 6.662 stykker kvæg til Folkeforsyningsrådet over to måneder inden 15 . marts 1920 af en gennemsnitlig vægt på 600 pund pr. styk. Dertil kom et antal kvæg til kredsenes eget forbrug. Kredsen skulle betale og udgiften efterfølgende blive refunderet af ernæringsrådet. Hver kreds skulle danne distriktskommissioner til besigtigelse og udpegning af leveringsegnet kvæg og kredsmodtagelseskommissioner, der stod for modtagelsen og kontrollen af det afleverede kvæg. Fordelingen blandt de fem kredse var udarbejdet på grundlag af kvægtællingen af 1. december 1919 og så ud som nedenstående:

\begin{tabular}{lccc}
\hline $\begin{array}{l}\text { Kreds/ } \\
\text { Aflevering }\end{array}$ & $\begin{array}{c}\text { Kredsens } \\
\text { eget forbrug } \\
\text { pr. uge }\end{array}$ & $\begin{array}{c}\text { Til Folke- } \\
\text { forsyningsrådet } \\
\text { pr. måned }\end{array}$ & $\begin{array}{c}\text { Til Folke- } \\
\text { forsyningsrådet } \\
\text { i \% }\end{array}$ \\
\hline Haderslev & 31 & 1166 & $35 \%$ \\
Sønderborg & 19 & 333 & $10 \%$ \\
Aabenraa & 14 & 500 & $15 \%$ \\
Tønder & 30 & 1200 & $36 \%$ \\
Flensborg landkreds & 14 & 132 & $4 \%$ \\
\hline I alt & 108 & 3331 & $100 \%$ \\
\hline
\end{tabular}

Kilde: Bekendtgørelser fra den internationale kommission. S. 58. LAA.

Fordelingen afspejler kredsenes geografiske størrelser og antallet af kvægbrug. Haderslev og Tønder kreds var de store kvægbrugsdominerede kredse. De 6.662 stykker kvæg var afstemningsområdets eksportvare til Tyskland, der til gengæld ville forsyne området med kul, sukker og bygningsmaterialer. Denne del af forsyningsordningen forekommer nationalpolitisk neutral. Men det sidste ord i den sag var ikke sagt.

\section{Afstemningstiden}

Da Versaillestraktaten endelig blev ratificeret den 10. januar 1920, trådte CIS i funktion som øverste myndighed i afstemningsområdet. Slesvig var fra da af internationalt administreret afstemningsområde, og valgkampen gik $i$ gang. Men på grund af de allierede besættelsestroppers forsinkede ankomst til afstemningsområdet, ankom CIS først til Flensborg den 25. januar. Af den grund blev anordningen om Folkeforsyningsrådet først udstedt den 26 . januar.

I perioden fra den 26. januar og frem til 14. juni 1920 blev der 


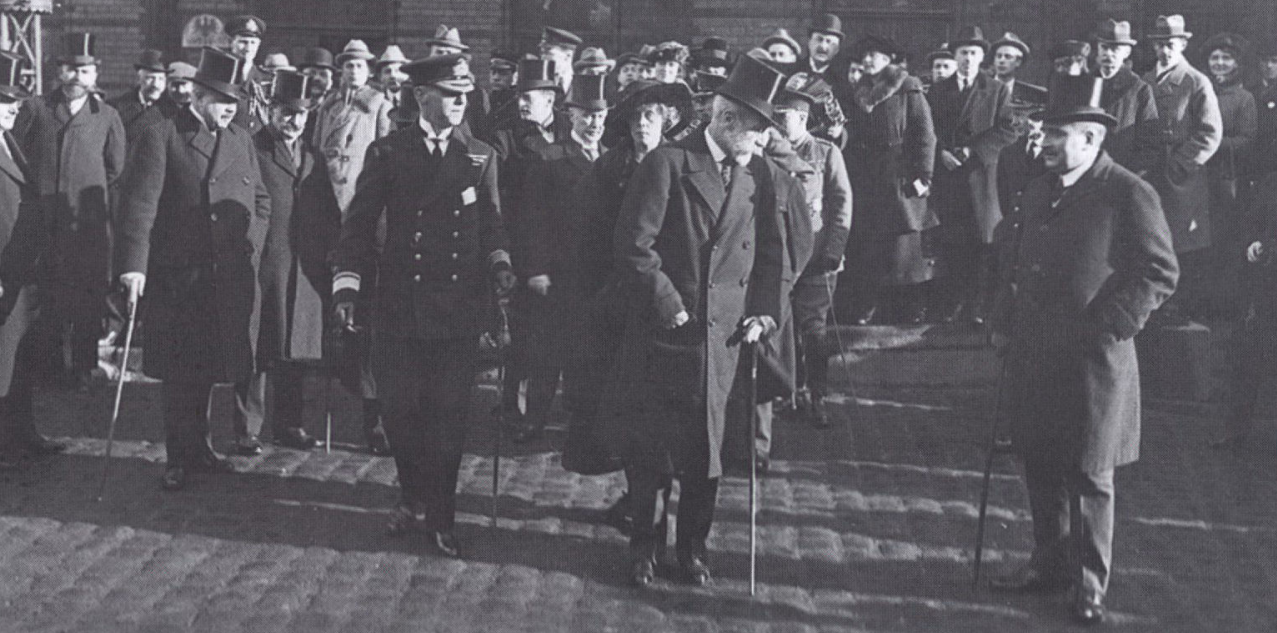

Den internationale kommission ankommer til Flensborg banegård 25. januar 1920. Fra venstre telegrafdirekter Thomas Heftye, professor Paul Verrier, admiral Sheppard, landshøvding Oscar von Sydow, Lady Marling, den britiske gesandt og kommissionens formand Sir Charles Marling og den franske gesandt Paul Claudel. Foto: Institut for Sønderjysk Lokalhistorie.

udstedt 36 anordninger og bekendtgørelser af og om Folkeforsyningsrådet. Den 31. januar bekendtgjorde Folkeforsyningsrådet en aftale med mejerierne $\mathrm{i}$ afstemningsområdet, hvori mejerierne forpligtede sig til så vidt muligt at forsyne befolkningen med 100 gram smør pr. person om ugen og med alle midler modarbejde smughandel på mejerierne. Den 14. februar måtte smørrationen dog sættes ned til 50 gram pr. person om ugen, formentlig fordi store mængder smør var blevet brugt ved bespisningen af de mange tilrejsende, der havde opholdt sig i zone I for at afgive deres stemme den 10. februar. Den 31 . januar bekendtgjordes de $\mathrm{i}$ afstemningstiden gældende maksimalpriser på basale fødevarer. Den 10 . februar, afstemningsdagen i zone I, bekendtgjorde Folkeforsyningsrådet, at kredsenes kvægafleveringer kunne erstattes med aflevering af svin og kalve. Desuden blev det forbudt at handle med svin udenom kredsmodtagelseskommissionen. Et tilbagevendende emne var ægforsyningen. Den 26. februar blev eksport af æg forbudt, indtil prisen igen var faldet til under 1 mark pr. æg. Den 6. marts blev hengemning og præservering af æg forbudt, 
og overtrædelse af forbudet kunne medføre bøder på op til 10.000 mark eller ét års fængsel. Manglen på æg har tilsyneladende været alvorlig. Den 31. marts måtte overførsel af kvæg fra zone II til zone I forbydes med undtagelse af kvæg på ejendomme, der lå på grænsen. ${ }^{46}$

Folkeforsyningsrådets bekendtgørelser giver et indblik $\mathrm{i}$ forsyningssituationen under CIS-styre. Det fremgår af bekendtgørelserne, at der var tale om en mangelsituation med hensyn til for eksempel smør og æg. Det fremgår også, at et stort problem i forsyningssituationen var spekulation og smughandel. Folkeforsyningsrådet havde ganske vist fået uindskrænket myndighed, men der foregik tydeligvis stadig transaktioner udenfor myndighedernes rækkevidde.

\section{Kvægafleveringsmodstand i Tønder kreds}

Da der i januar 1920 blev slået en streg over kvægrestancerne fra efteråret 1919, regnede CIS og Folkeforsyningsrådet med, at kvægafleveringerne $i$ afstemningstiden ville forløbe uden problemer. Det var også tilfældet i de fire østlige kredse Haderslev, Aabenraa. Sønderborg og Flensborg Landkreds. Her strttede landboforeningerne Folkeforsyningsrådets anordninger ${ }^{47}$ Men i Tønder kreds var der til gengæld problemer. I februar og marts 1920 blev der afholdt flere protestmøder mod kvægafleveringerne. ${ }^{48}$ Schleswig-Holsteinischer Bauernverein, der var oprettet under krigen som protestbevægelse mod tvangsafleveringerne, og en sammenslutning ved navn Viehverwertungsgenossenschaft ledede protesterne. Sidstnævntes formand, Mommsen, udtalte sig så kritisk i mod CIS' myndighed, at CIS i februar så sig foranlediget til at arrestere Mommsen, der dog hurtigt blev løsladt igen. Protesten gik på, at de fleste landejendomme på vestegnen var så små, at de ikke kunne medvirke i afleveringerne uden at miste op til halvdelen af deres besætning. Det betød til gengæld, at de få større landmænd måtte bære en større del af afleveringerne, hvilket de pågældende organisationer anså for uretfærdigt. Professor Møllgaard deltog den 2. marts i et protestmøde i Tønder for at forklare Folkeforsyningsrådets syn på sagen. Møllgaard foreslog her, at de små landmænd gik sammen om afleveringerne og udlignede afleveringerne kontant imellem hinanden. Møllgaard hævdede desuden, at han ville arbejde for, at den danske stat betalte landmændene en godtgørelse for deres kvægafleveringer, når Danmark 
havde overtaget administrationen. Problemet var, at et sådan løfte ikke kunne gives offentligt, fordi "vilde vi nu love guld og grønne skove, så vilde tyskerne med fuld ret kunde fremhæve noget sådant som forsøg på stemmekøb. Det vilde være en politisk erklæring fra vor side, en erklæring som, vilde forhindre en hæderlig og ærlig afgørelse «. ${ }^{49}$ Det problem var tilsyneladende ikke større, end at løftet kunne gives ved protestmødet i Tønder, der dårligt kan betegnes som andet end offentlig.

Møllgaard havde før foreslået, at de nordslesvigske landmænd skulle have godtgørelse for deres brødkornsafleveringer. Det var gledet ud, da de tyske repræsentanter ikke godkendte forslaget, og CIS i stedet hentede brødkorn i Danmark til de forsørgelsesberettigede i afstemningsområdet. Møllgaard ville nu arbejde for efterbetaling på kvægafleveringerne. I første omgang førte protesterne i Tønder kreds til udstedelsen af en anordning, hvor i Folkeforsyningsrådet fik fuldmagt til at påkræve kredsene at tvangsinddrive kvæget for landmændenes egen regning. ${ }^{50}$ Det blev ifølge Møllgaards egen rapport ikke nødvendigt. Kort tid efter mødet den 2 . marts begyndte afleveringerne fra Tønder kreds at blive opfyldt.

At kvæg-for-kul-ordningen til dels fungerede efter hensigten viste professor Møllgaard i sin beretning til Rigsdagspartiernes sønderjyske Udvalg den 6. april 1920. Møllgaard fremviste resultaterne af kvægafleveringer pr. 6. marts 1920. 1.575 stykker kvæg var leveret til Flensborg by og 2.188 stykker kvæg var leveret til Tyskland. I alt var 3.763 stykker kvæg afleveret, hvilket var lidt over halvdelen af det i bekendtgørelsen af 26 . januar fastsatte antal. Kvæget udgjorde en værdi af 2.969.246 mark. Danmark havde derudover leveret 150 tons margarine til en værdi af $\mathbf{2 . 4 0 0 . 0 0 0 ~ m a r k ~ t i l ~ T y s k l a n d ~ s o m ~ k o m p e n s a - ~}$ tion for kulleverancer til afstemningsområdet. Tyskland havde således samlet modtaget leverancer til en værdi af 5.369.246 mark. Tyskland havde til gengæld leveret 20.728 ton kul til afstemningsområdet i perioden 10. januar til 10. februar 1920 til en værdi af 4.145 .702 mark. En opgørelse over kulleverancer siden 10 . februar indeholdt beretningen ikke, men de nævnte tal tyder på, at en vis udligning fandt sted. ${ }^{\mathbf{1}}$

\section{Kronepriser på brødkorn og kvæg}

Afstemningen i zone II den 14. marts var et vendepunkt for den administrative og praktiske forberedelse af de sønderjyske landsdeles 
indlemmelse i Danmark. Det var fortsat usikkert, præcist hvor stor en del af afstemningsområdet der skulle indlemmes i Danmark. Forslag om Flensborgs internationalisering og Tiedje-linien hang stadig uafklaret i luften. Meget talte dog for, at hele zone I ville blive dansk, og forberedelser på indlemmelse af dette område blev fra dansk side intensiveret. På den måde kunne det tyske forslag om en Tiedjegrænselinie nord om Tønder lide en stille død.

Også på forsyningsområdet var 14. marts et vendepunkt. Professor Møllgaard kunne nu opfylde sine løfter til landmændene i Tønder. Den 19. marts 1920, fem dage efter afstemningen, lod han på den danske stats brødkornsadministrations vegne en erklæring trykke i den sønderjyske dagspresse. Her i stod, at landmænd bosiddende inden for det område, der blev dansk, ville få $60 \%$ af det brødkorn, de havde afleveret til Reichgetreidestelle og Folkeforsyningsrådet betalt efter den danske kornlovs priser. Forskellen på den tyske og danske pris fortæller i eget sprog, hvorfor efterbetalingen var af stor betydning. I tyske priser fik landmanden 4 kroner pr. 100 kilogram brødkorn, mens han i danske priser ville få 30 kroner pr. 100 kilogram. Differencen var således 26 kroner pr. 100 kilogram, som brødkornsadministrationen ville efterbetale for $60 \%$ af afleveringens vedkommende. Med hensyn til kvægafleveringen ville landmænd inden for det til Danmark tilfaldende område få 20 øre ekstra betaling pr. pund levende kød, de havde afleveret $i$ henhold til anordningen af 26. januar 1920. Aftalen var udformet af Møllgaard, H. P. Hanssen, designeret landråd i Haderslev og formand for Fælleslandboforeningen i Nordslesvig P.J. Refshauge samt tidligere landdagsmand Nis Nissen. ${ }^{52}$ Møllgaard mere end opfyldte sine løfter til landmændene i Tønder kreds, da den omtalte godtgørelse ikke blot omhandlede det afleverede kvæg, men også brødkorn. Afstemningerne var afholdt og erklæringen kunne ikke længere anklages for at være et forsøg på at påvirke stemmeafgivelserne.

Den 20. april 1920 kom Møllgaards efterbetaling af brødkorn til de nordslesvigske landmænd til drøftelse i Rigsdagspartiernes sønderjyske Udvalg. Efterbetalingen blev bragt i sammenhæng med et forslag om indførelse af 5000 tons foderstoffer $\mathrm{i}$ form af majs og oliekager til zone I. Foderstofferne skulle uddeles til landmændene i bytte for det brødkorn, de havde afleveret eller ville aflevere til kredsmyndighederne. Byttet med foderstoffer skulle ske efter danske kornlovspriser, og brødkorn, der ikke blev byttet med foderstoffer, skulle efterbetales 
kontant. Det vil sige 26 kroner pr. 100 kilo brødkorn, der var afleveret til kredsmyndighederne siden 26. januar, og 30 kroner pr. 100 kilo brødkorn, der siden ville blive afleveret til den danske stats brødkornsadministration. Den samlede mængde brødkorn, der blev byttet med foderstoffer eller betalt i danske kornlovspriser, måtte ikke udgøre over $60 \%$ af det brødkorn, landmændene ville aflevere i høståret 191920. Møllgaard regnede med, at den samlede mængde afleverede brødkorn i høståret $1919-20$ ville udgøre $180.000 \mathrm{hkg} .60 \%$ af denne mængde var $110.000 \mathrm{hkg}$, hvoraf 5.000 tons skulle byttes med foderstoffer og 6.000 tons betales i danske priser. Operationen ville koste 2.960 .000 kroner. Forslaget blev vedtaget, og de små 3 millioner kroner bevilget. Forinden havde nu forhenværende minister H.P. Hanssen fortalt, at foderstofmanglen var så alvorlig, at landmændene var tvunget til at sælge kvæget og det helst i Danmark til kronepriser. ${ }^{53}$

Den 22. april bekendtgjorde Folkeforsyningsrådet, at alt afleveringspligtigt brødkorn skulle afleveres til kommunalforbundene inden den 10. maj 1920. Kornet ville blive betalt med 41 mark pr. 100 $\mathrm{kg}$ rug og 46 mark pr. $100 \mathrm{~kg}$ hvede, i danske priser omtrent 4 kroner pr. $100 \mathrm{~kg}$ brødkorn. Afleveringer efter den 10. maj ville ikke blive efterbetalt af den danske stat. Den danske stats efterbetaling var som sagt 26 kroner pr. $100 \mathrm{~kg}$. Afleveringsincitamentet var til at få øje på.

\section{Adskillelsen af zone I og zone II og kronemøntens indførelse}

Afstemningen i zone I gav $75 \%$ danske stemmer og $25 \%$ tyske stemmer, og afstemningen i zone II $20 \%$ danske og $80 \%$ tyske stemmer. Resultaterne tillod den prognose, at zone I ville blive indlemmet $\mathbf{i}$ Danmark, mens zone II ville forblive ved Tyskland. Det var op til CIS at foreslå en grænselinie på baggrund af afstemningerne. Der skulle igen gå længere tid end forventet, før en endelig afgørelse blev truffet - ikke mindst på grund af afsættelsen af regeringen Zahle og påskekrisen i Danmark sidst i marts 1920. Glæden over resultatet var stor hos de dansksindede i zone $\mathrm{I}$, men efterhånden som indlemmelsen i Danmark trak ud, blev glæden afløst af et stadig oftere stillet spørgsmål der lød: Hvornår kommer kronemønten?

Rigsdagspartiernes sønderjyske Udvalg havde vedtaget en ordning på valutaspørgsmålet den 26. marts 1920, men kronemøntens indførelse var afhængig af, at toldgrænsen blev flyttet fra Kongeåen til 
sydgrænsen af zone I. Toldgrænsen skulle forhindre indførslen af varer fra Tyskland, der uhindret kunne påvirke prisfastsættelsen. Her stødte CIS på et problem, da Tyskland ikke ville anerkende toldgrænsens flytning før den endelige suverænitetsoverdragelse. CIS måtte handle varsomt $i$ denne sag, fordi Tysklands accept af suverænitetsoverdragelsen var vigtig. Derfor forhandlede CIS i længere tid med Tyskland om toldgrænsespørgsmålet. I sidste ende måtte CIS gå uden om Tyskland. Den 29. april vedtog CIS på forslag af den danske regerings repræsentant grev Reventlow, at grænsen mellem zone I og II skulle afspærres og Danmark besætte zone I og overtage administrationen den 5. maj 1920. Toldgrænsen kunne derimod blive ved Kongeåen. ${ }^{54} \mathrm{Da}$ afspærringen af grænsen og den danske besættelse var gennemført 5. maj, kunne CIS den 14. maj 1920 udstede en bekendtgørelse om kronemøntens indførelse, der skulle foregå den 20. maj.

Besættelsen og kronemøntens indførelse i zone I betød, at zone I og II blev administrativt adskilt. En række anordninger herom blev udstedt 14. maj, herunder adskillelsen af forsyningsadministrationen. Forsyningsadministrationen i zone I ville overgå til ernæringsinspektoratet i Aabenraa, der overtog alle rettigheder og forpligtelser fra Folkeforsyningsrådet. Folkeforsyningsrådet beholdt forsyningsadministrationen i zone II samt administration af kulforsyningen $\mathrm{i}$ både zone I og II. Folkeforsyningsrådet skulle påse, at der i tidsrummet 15. maj til 31. juli 1920 blev tilført zone I 15.000 tons kul. Willy Iversen blev øverste leder af Folkeforsyningsrådet, mens Holger Møllgaard blev leder af ernæringsinspektoratet i Aabenraa.

Mens Folkeforsyningsrådets anordninger om forsyningsforhold forblev i kraft i zone II, blev en række nye anordninger udstedt for zone I. Handelen med kød, svin, kalve, fisk, havre, byg, margarine og smør blev frigivet. Det vil sige, at afleveringspligt og rationeringer ophævedes. Dog skulle det af 26. januar bestemte antal kvægafleveringer opfyldes. En ny brødkornsordning trådte i kraft den 20. maj. Landmændene ville få 4 kroner pr. 100 kilo brødkorn i betaling fra de nye amter. Til gengæld ville ernæringsinspektoratet efterbetale 26 kroner pr. 100 kilo for $60 \%$ af den samlede brødkornslevering. Priser på levering fra amter til møllere og fra møllere til bagere blev fastsat i samme anordning. Bagere måtte sælge rugmel til forbrugere for højst 21 øre kiloet og hvedemel for 64 øre kiloet. Rugbrød måtte ikke sælges for over 24 øre kiloet. ${ }^{55}$ Til sammenligning var de gamle mak- 
simalpriser på rugmel i detailhandel 105 mark pr. 100 kilo og på hvedemel 119 mark pr. 100 kilo. I maj 1920 var markkursen gennemsnitlig 14 kroner for 100 mark. Omregnes de gamle maksimalpriser til kronepriser, var det 14 øre pr. kilo rugmel og 17 øre pr. kilo hvedemel. Kronemøntens indførelse betød således, at prisen på rugmel steg med 7 øre pr kilo og prisen på hvedemel med 47 øre pr. kilo. Det er prisstigninger på omtrent $50 \%$ og $150 \%$.

Prisstigningerne på brødkornsmel var udtryk for en generel tendens. Da kronemønten var indført den 20. maj, steg priserne i zone 1 eksplosivt. Frigivelsen af handelen for en lang række varer, afspærringen af grænsen til både syd og nord og kronemøntens højere værdi var årsag til den eksplosive stigning. Kronemøntens indførelse gav derfor ikke den ro, CIS havde forventet. I stedet udbrød der demonstrationer og fra den 3.-15. juni generalstrejke blandt arbejderne i købstæderne. Arbejdernes krav var 2 kroner i timeløn, hvilket lå over den danske standard på 1,60 kroner i timen. CIS reagerede den 7. juni med at udstede en anordning om oprettelsen af prisreguleringskommissioner i hvert amt. Hensigten var at sørge for, at fødevarepriserne ikke oversteg de i Danmark gældende maksimalpriser, hvad der altså nu må have været tilfældet. Først den 12. juni lykkedes det med H.P. Hanssens medvirken at nå frem til et forlig. Arbejderne skulle have løn efter den i Danmark gældende overenskomst. Til gengæld ville arbejdsgiverne tilstræbe at forbrugspriserne blev holdt nede på et tilsvarende niveau. 15. juni 1920 genoptog arbejderne deres arbejde. Samme dag notificeredes den nye grænse af ambassadørrådet i Paris, og suveræniteten over Nordslesvig blev overført til Danmark. I anordning nr. 159, den sidste af slagsen, bekendtgjorde CIS, at dens myndighed fra og med den 16. juni 1920 var ophævet. ${ }^{56}$ Dermed var afstemningstiden overstået, og Nordslesvig blevet en del af Danmark.

\section{Ernæringsordningens regnskab}

Den 4. december 1920 gjorde Holger Møllgaard statens brødkornsadministrations regnskab for ernæringsordningen $i$ afstemningsområdet op overfor Landbrugsministeriet. Den samlede bevilling fra Rigsdagspartiernes sønderjyske Udvalg til ernæringsforholdene i afstemningsområdet var 7.020.000 kroner. 4.020 .000 kroner var blevet bevilget den 26. november 1919 og 3.000 .000 blev bevilget den 20. april 1920. Ud- 
gifterne kunne samlet gøres op til 6.089 .000 kroner, og der var således 931.000 kroner i overskud. Regnskabet så ud som vist nedenstående.

Udgifter til ernæringsordningen i afstemningsområdet januar-juni 1920

\begin{tabular}{lr}
\hline Art & \multicolumn{1}{c}{ Udgift } \\
\hline Efterbetaling på korn & $1.245 .366,30$ \\
Ombytning af vintersæd & $121.602,66$ \\
Efterbetaling på kvæg & $889.104,55$ \\
Sønderjyllands vareforsyning & \\
$\quad$ Margarine & $1.815 .575,96$ \\
$\quad$ Rugmel & $173.974,95$ \\
Hvedemel & $200.260,65$ \\
Hvede & $344.699,66$ \\
Rugmel & $594.017,99$ \\
$\quad$ Kul & $326.359,85$ \\
$\quad$ Diverse varer & $64.758,20$ \\
$\quad$ Diverse omkostninger & $70.206,89$ \\
Vareforsyning i alt & $3.589 .854,15$ \\
Prisregulering på rug i tiden 20. maj-15. september 1920 & $298.766,50$ \\
Samlet udgift & $6.144 .694,16$ \\
Overskud fra Ernæringsinspektoratets administration & $-55.642,75$ \\
\hline Gæld til Statens Brødkornsadministration & $6.089 .051,41$ \\
\hline
\end{tabular}

Kilde: Finansministeriet/Statsbogholderikontoret/Sager vedr. de sønderjyske Landsdele 1920-22. Rigsarkivet.

Den danske stat havde haft en udgift på 6.089.051,41 kroner til ernæringsordningen $\mathrm{i}$ afstemningsområdet $\mathrm{i}$ perioden januar til juni 1920. 3.589.854 kroner gik til fødevareforsyning af afstemningsområdet, og 2.554 .840 kroner var givet som efterbetaling og regulering på afleveret brødkorn og kvæg. 6 millioner kroner var ganske mange penge i 1920. Det svarede stort set til Ministeriet for offentlige Arbejders udgifter i finansåret 1919-20 på 6,4 millioner kroner, eller halvdelen af landbrugsministeriets udgifter på 11,7 millioner kroner i samme finansår. ${ }^{57}$ Kulleverancer og fra marts 1920 kornleverancer fra Tyskland til afstemningsområdet har til dels opvejet den danske udgift, men der er ikke fundet dokumentation for en egentlig udligning eller refundering af udgifterne fra Tysklands side. Desuden blev kulforsyningen fra Tyskland også betalt med 6.662 stykker kvæg fra afstemningsområdet og margarine fra Danmark. Forsyningerne til afstemningsområdet indgik tilsyneladende heller ikke $i$ de finansielle mellemværender mellem Danmark og Tyskland efter indlemmelsen af Nordslesvig. 
Ved professor Møllgaards regnskabsaflæggelse i december 1920 bad Finansministeriet ham om at beskrive, hvad aftalen mellem daværende finansminister Edvard Brandes og brødkornsadministrationen havde drejet sig om. Brødkornsadministrationen havde tilsyneladende ikke fået sine udgifter refunderet af Finansministeriet. Det vidner om de ekstraordinære lovgivningsforanstaltninger, der var tale om i forbindelse med genforeningen. Reelt var Rigsdagspartiernes sønderjyske Udvalgs bevillinger til afstemningsområdet en omgåelse af grundlovens § 48: »Ingen udgift må afholdes, som ikke har hjemmel i den af Rigsdagen vedtagne finanslov eller i en af Rigsdagen vedtaget tillægsbevillingslov eller midlertidig bevillingslov. ${ }^{58}$ Men der var også tale om helt ekstraordinære tilstande, som krævede fleksible forvaltningsgange.

\section{En fri og retfærdig afstemning}

"Spørgsmål om fødevareforsyning og rent kommercielle emner må ikke hindre udførelsen af en fri og retfærdig afstemning. « Sådan lød det overordnede princip $i$ den internationale kommissions administration af ernærings- og forsyningsforholdene $i$ afstemningsområdet. Hermed mentes først og fremmest, at fødevaremangel og deraf følgende sociale uroligheder ikke måtte forhindre afstemningen. Denne operation lykkedes. Ganske vist var fødevarerne knappe, priserne høje og smughandelen meget udbredt, og økonomisk og materielt kom den slesvigske befolkning noget tilredt ud af overgangstiden 1918-20. Men uroligheder i større målestok var man blevet forskånet for, og afstemningerne var blevet afholdt i nogenlunde fordragelighed. Det skyldtes blandt andet, at forsyningsforholdene blev udbedret ved bevillinger og tilførsler fra Danmark.

Bevillingerne fra Danmark løste en central problemstilling i afstemningsområdets forsyningsforhold. Kronepriserne sneg sig i forventningen om den snarlige overgang til Danmark ind på alle områder $\mathbf{i}$ den nordslesvigske økonomi. Landarbejdere forlangte allerede $i$ foråret 1919 lønninger udbetalt i danske kroner, og mange af landmændenes øvrige udgifter lå også på det sorte marked, hvor alt betaltes i kronepris. Indtægter for afleveringer til tyske maksimalpriser kunne ikke dække udgifter i kronepriser. De tyske maksimalpriser måtte imidlertid opretholdes af hensyn til forbrugerne eller de såkaldt forsørgelsesberettigede. Dette modsætningsforhold mellem forbrugere 
Dansk afstemningsplakat fra 1920 tegnet af Thor Bogelund og tekst af Hans Ahlmann. Den bitre nod vil ophøre, når fanen atter er red og hvid. P\&̊ grund af den materielle nød $i$ efterkrigstidens Tyskland, kunne valgplakatens udsagn dårligt opfattes som andet end et lofte om forbedrede materielle vilkair under dansk styre. Hvorvidt materielle forhold og fodevareforsyningen fra Danmark har pavvirket stemmeafgivelserne er dog uvist. Foto: Museet på Sønderborg Slot.

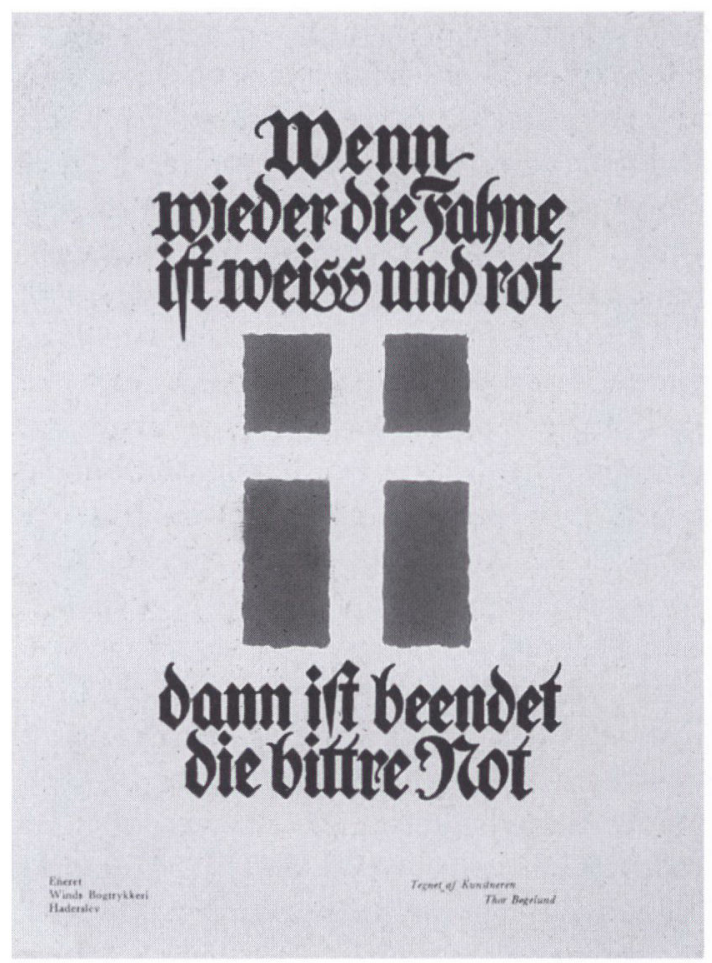

og producenter blev reduceret med tilførslerne fra Danmark og efterbetalingen for korn og kvæg.

Men i princippet om at fødevareforsyningen ikke måtte få indflydelse på en fri og retfærdig afstemning, lå som bekendt også, at fødevareforsyningen skulle holdes fri for nationalpolitik.

I afstemningsvalgkampen havde man fra dansk side faktisk slået på, at en fremtid i Danmark betød højere velfærd og levestandard. Det gav anledning til det tyske skældsord "Speckdänen" om folk, der stemte dansk af materielle grunde. ${ }^{59}$ Særlig valgkampen i zone 2 handlede om økonomiske fordele og ulemper ved de to alternative nationale valgmuligheder.

Spørgsmålet er, om fødevareforsyningen fra Danmark kan have påvirket stemmeafgivelsen? Det findes der ingen målinger på, og udtalelser herom kan kun blive gisninger. Også fra det i december 1918 privat oprettede Sønderjysk Fond kom der forsyninger til afstemningsområdet. Sønderjysk Fond blev dannet med henblik på at iværk- 
sætte en stor indsamling til opgaver af humanitær art i Sønderjylland efter krigen. Således blev der den 3. marts 1919 sendt 23 jernbanevogne med tøj til Nordslesvig. Fra maj 1919 sendte Sønderjysk Fond også levnedsmidler til afstemningsområdet, og i julen 1919 sendtes 11 jernbanevogne med fødevarer til Nordslesvig. ${ }^{60}$ Fødevarehjælpen fra Danmark var således omfattende og meget synlig i afstemningstiden og kan på den måde have givet incitament til at satse på tilslutning til Danmark. Professor Møllgaard var klar over, at forsyningerne fra Danmark og den danske efterbetaling for brødkorn og kvæg var i konflikt med princippet om fødevareforsyningens adskillelse fra national politik. Møllgaard omtaler dette forhold i flere af sine beretninger. Men det må også erindres, at nødtilstanden i afstemningsområdet var reel og kunne udgøre en trussel mod afstemningerne i form af social uro. Tyskland var præget af voldsom social og politisk uro i de umiddelbare efterkrigsår, hvorfor truslen måtte tages alvorligt. Desuden udeblev forsyninger fra Tyskland til afstemningsområdets nordlige dele fra foråret 1919, hvor man kunne forudse, at der skulle stemmes. De tyske myndigheder havde siden januar 1915 haft grundlæggende store vanskeligheder ved at opretholde en tilstrækkelig fødevareforsyning i Tyskland ${ }^{61}$ De manglende forsyninger fra Tyskland og det tyske krigsernæringsvæsens fejlslagne fødevarepolitik var derfor lige så mærkbare som forsyningerne fra Danmark. Havde de danske forsyninger betydning for stemmeafgivelserne, havde de manglende forsyninger fra Tyskland det også. Fire års krigstilstand havde skabt nødtilstande $\mathrm{i}$ afstemningsområdet, der ikke kunne siddes overhørig i det Danmark, der ville indlemme dele af dette område.

\section{KILDEMATERIALE}

Haderslev Krigsernæringsvæesens arkiv pk. 1 LAA (Landsarkivet i Aabenraa).

H.P. Hanssens privatarkiv. Pk.nr 159. LAA.

Finansministeriet/Statsbogholderikontoret/Sager vedr. de sønderjyske Landsdele 1920-22. Rigsarkivet.

F.O. 852. Danica 600 Public Record Office London. Mikrofilm Rigsarkivet

Bekendtgørelser fra den Internationale kommission. LAA.

Rigsdagspartiernes sønderjyske Udvalg. Forhandlingsprotokol. LAA.

\section{LITTERATUR}

Andersen, Morten (2002): "Det nordslesvigske valutasporgsmål 1918-1920 og kronemøntens indførelse. « $i$ Sønderjyske Årbeger 2002.

Becker-Christensen, Henrik (1995): "Den nye grænse." i Henrik Becker-Christensen (red.) Grænsen i 75 år 1920-1995. s. 24-43. Institut for Grænseregionsforskning Aabenraa.

Callø, P.A. (1922): »De økonomiske forhold i Senderjylland i overgangstiden " I National-økonomisk Tidsskrift for Samfundsspørgsmaal, Økonomi og 
Handel. 1922. s. 188-229. Nordisk forlag. København.

Fangel, Henrik (1996): Haderslev bys historie 1864-1920. Historisk Samfund for Sønderjylland nr. 74. Haderslev og Aabenraa.

Feldman, Gerald D. (1997): The Great Disorder. Politics, Economics and Society in the German Inflation, 1914-1924. Oxford University Press.

Fink, Troels (1979): Da Sønderjylland blev delt Bd. I-III. Institut for grænseregionsforskning. Aabenraa.

Japsen, Gottlieb (1970): De nordslesvigske sparekassers historie. Historisk Samfund for Sonderiylland. nr. 41. Aabenraa.

Klos, Michael (1996): "Krisen på hjemmefronten 1914-1918 - med Flensborg som eksempel.» i Sønderjyske Årbøger 1996.

Kretzschmer, Knud (1960): Den senderjydske Fond 1918-1960. Historisk Samfund for Sønderjylland nr. 20. Aabenraa.

Møller, Peter J. (1978): Haderslevdreng mellem tysk og dansk. Historisk Samfund for Sønderjylland. Aabenraa.

Nicolai, Britta (1988): Die Lebensmittelversorgung in Flensburg 1914-18. Flensburg.

Poulsen, Marten Refslund (1957): Erindringer. 2. del. Genforeningen i Nordslesvig. Det danske forlag. København.

Schultz Hansen, Hans (1994): Det sønderjyske landbrugs historie 1830-1993. Historisk Samfund for Sønderjylland $\mathrm{nr}$. 72. Aabenraa.

Østergaard Schultz, Annette (1996): Mellem Fjelstrup og fronten. Inger og Jørgen Friis - breve 1915-18. Historisk Samfund for Senderjylland. nr. 75. Aabenraa

Winkler, Heinrich August (1998): Weimar 1918-1933. Die Geschichte der ersten deutschen Demokratie. Verlag C.H. Beck. München.

\section{NOTER}

1. Nicolai s.22-24 og Calle 188-192.

2. Schultz Hansen s. 213, Østergaard Schultz s. 226-227 og Nicolai s. 79-85. Flensborg by indgik i foråret 1915 aftale med Flensborg Landkreds om fælles selbstwirtschaftsstatus efter at have forhandlet med både Haderslev, Sonderborg, Slesvig og Flensborg Landkreds om et samarbejde. Haderslev kreds opnåede selvstændigt selbstwirtschaftsstatus.

3. Schultz Hansen s. 212-214, Feldman s. 58 og Nicolai s. 79-80.

4. Feldman s. 66-67.

5. Meddelelse fra overpræsidenten til landråder 23. februar 1917 og Tjenestebog om Kriegswirtschaftsämter. Berlin 1917. Haderslev Amts krigsernæringsvæsen pk. 1 LAA.

6. Klos s. 155-159.

7. Feldman s. 68-80.

8. Winkler s. 17-28.

9. Becker-Christensen s. 27-28.

10. Haderslev Krigsernæringsvæsens arkiv pk. 1 LAA.

11. Feldman s. 127-130.

12. Fangel s. $405-415$, Rigsdagspartiernes sønderjyske Udvalg. Forhandlingsprotokol s. 54-55 og Japsen s. 303.

13. Andersen s. 75-78.

14. Peter J. Møller s. 58-61.

15. Haderslev Krigsernæringsvæsen Arkiv pk. 1 LAA.

16. Se Troels Fink: Da Sønderjylland blev delt bd. II kap. 5 .

17. Det midlertidige ministerium bestod af minister H.P. Hanssen, kontorchef Martin Hammerich og sekretær Anders Thulstrup.

18. Rigsdagspartiernes sønderjyske Udvalg. Forhandlingsprotokol s. 11-12.

19. Kommission til overvågelse af afstemningen i Slesvig.

20. Fink: Da Sonderjylland blev delt bd. II s. 165-166. Om Tyskland se Winkler: Weimar 1918-1933. (1998)

21. Rigsdagspartiernes sønderjyske Udvalg. Forhandlingsprotokol s. 108109.

22. Ibid s. 122.

23. H.P. Hanssens privatarkiv. Pk. nr 159 Læg: Korrespondancesager vedr. Valutaspergsmålet.

24. Hejmdal 2. september 1919.

25. Der blev talt om »hullet i vesten « med hensyn til de besatte områder $i$ vest, hvor varer strømmede ud af Tyskland. Se Feldman s. 174-175.

26. H.P. Hanssens privatarkiv. Pk. 159. Korrespondance vedr. levnedsmiddelforsyningen til Nordslesvig. 
27. Ibid.

28. Rigsdagspartiernes sønderjyske Udvalg. Forhandlingsprotokol s. 264265.

29. H.P. Hanssens privatarkiv. Pk. 159. Redegørelse af prof. Mølgaard af april 1920 + udkast til ordning af levnedsmiddeladministration af 6 . november 1919.

30. H.P. Hanssens privatarkiv. Pk. 159. Brev og udkast til det midlertidige min. af 7. november 1919.

31. Rigsdagspartiernes sønderjyske Udvalg. Forhandlingsprotokol s. 322323.

32. Ibid s. 324-327.

33. Andersen s. 92.

34. Rigsdagspartiernes sønderjyske Udvalg. Forhandlingsprotokol s. 748. Redegorelse for Forhandlingerne mellem den internationale Kommissions danske Ernæringskommissær og Tysklands repræsentanter vedrørende Ernæringsforholdene i det slesvigske Afstemningsområde.

35. "Rapport til den internationale kommission vedrørende Forsyningen af det slesvigske Afstemningsområde." 27/12-1919. Finansministeriet/Statsbogholderikontoret/Sager vedr. de sønderjyske Landsdele 1920-22. Rigsarkivet.

36. Ibid.

37. "Entwurf zu einem Vertrag zwischen der Deutschen Regierung und der Internationalen Kommission.« 22/121919. Finansministeriet/Statsbogholderikontoret/Sager vedr. de sønderjyske Landsdele 1920-22. Rigsarkivet.

38. Rigsdagspartiernes sønderjyske Udvalg. Forhandlingsprotokol s. 748.

39. Hejmdal 29. december 1919 »Kvægafleveringen «.

40. F.O. 852 - 24. Danica 600 Public record Office London. Mikrofilm Rigsarkivet.

41. Bekendtgørelser fra den internationale kommission. S. 51. LAA.

42. Ibid s. 52.

43. F.O. 852 - 16. Danica 600 Public re- cord Office London. Mikrofilm Rigsarkivet.

44. Rigsdagspartiernes sønderjyske Udvalg. Forhandlingsprotokol s. 748. Redegorelse for Forhandlingerne mellem den internationale kommissions danske ernæringskommissær og Tysklands repræsentanter vedrørende ernæringsforholdene $\mathbf{i}$ det slesvigske afstemningsområde.

45. Bekendtgørelser fra den internationale kommission. S. 56. LAA.

46. Bekendtgørelser fra den internationale kommission. LAA.

47. Således findes en artikel i Hejmdal 29. januar 1920 med titlen. "Kreaturudtagningen. De forskellige Landbrugsorganisationer i Aabenraa Amt tilsiger deres støtte.《

48. Blandt andet et stort møde den 20 . februar 1920 i Skyttehuset. Hejmdal 25. februar 1920.

49. Hejmdal 3. marts 1920. Kvægafleveringen. Et møde i Tønder i Gaar.

50. Bekendtgørelser fra den internationale kommission. S. 83. LAA.

51. Rigsdagspartiernes sønderjyske Udvalg. Forhandlingsprotokol s. 756757.

52. Hejmdal 19. marts 1920 og Rigsdagspartiernes sonderjyske Udvalg Forhandlingsprotokol s. 639 (4. marts).

53. Ibid s. 808-814.

54. F.O. 852 - 16. Danica 600 Public record Office London. Mikrofilm Rigsarkivet. $\mathrm{Om}$ Valutaspørgsmålet se Andersen 2002.

55. Bekendtgørelser fra den internationale kommission. S. 119-159. LAA.

56. Bekendtgørelser fra den internationale kommission. s. 173-182. og Andersen (2002) s. 111-114.

57. Statistisk Aarbog 1921. Danmarks Statistik. s. 188-189.

58. Danmarks Riges Grundlov. Lovtidende 1915. s. 11-624.

59. Becker-Christensen s. 40.

60. Se Kretzschmer: Den sønderjydske Fond 1918-1960 (1960).

61. Feldman s. 166-167. 